\title{
A Robust Vanadium(V) Tris(2-pyridyl)borate Catalyst for Long-Lived High-Temperature Ethylene Polymerization
}

\author{
Jin Qian, Robert J. Comito* \\ The University of Houston, Houston, Texas 77004
}

Supporting Information

\section{Contents}

1. General Information $\quad$ S3

2. Preparation of Vanadium Precatalysts $\quad$ S4

3. Spectral Data for Vanadium Precatalysts $\quad$ S9

4. X-ray Structure determination of $\mathrm{TpyV}(=\mathrm{NPh})(\mathrm{OiPr})_{2}(\mathbf{1}) \quad \mathrm{S} 19$

5. Ethylene Polymerization $\quad$ S22

6. Gel Permeation Chromatography Data for Polymer Products S37

7. Calorimetry Data for Polymer Products $\quad$ S39

8. Spectral Data for Polymer Products $\quad$ S44 
10. Comparison with Reported Vanadium Catalysts at High Temperature 
S1. General Information. Trimethylaluminum, modified methylaluminoxane-12 (MMAO-12) and methyl aluminum dichloride were purchased from commercial sources and used as is. Depleted $\mathrm{MMAO}^{1}$ and dimethyl aluminum chloride ${ }^{2}$ were prepared according to the literatures. Other commercial reagents were purified prior to use following the guidelines of Perrin and Armarego. ${ }^{3}$ All solvents were purified according to the method of Grubbs. ${ }^{4}$ Yields refer to pure compounds, unless otherwise indicated. All reactions were performed in an atmosphere of dry, oxygen-free dinitrogen using standard Schlenk techniques.

${ }^{1} \mathrm{H}$ NMR spectra were recorded on a JEOL (400 MHz) and are internally referenced relative to residual portion solvent signals $\left(\mathrm{CDCl}_{3}\right)$ at $\delta=7.26 \mathrm{ppm}\left({ }^{1} \mathrm{H}\right), 1,1,2,2-$ tetrachloroethane-d2 at $\delta=6 \mathrm{ppm}$, and $\mathrm{C}_{6} \mathrm{D}_{6}$ at $\delta=7.16 \mathrm{ppm}$. Data for ${ }^{1} \mathrm{H}$ NMR are reported as follows: chemical shift $(\delta \mathrm{ppm})$, multiplicity $(\mathrm{s}=\operatorname{singlet}, \mathrm{d}=$ doublet, $\mathrm{t}=$ triplet, $\mathrm{q}=$ quartet, $\mathrm{m}=$ multiplet, $)$, integration, and coupling constant $(\mathrm{Hz}) .{ }^{13} \mathrm{C}$ spectra were recorded on a JEOL $(101 \mathrm{MHz})$ and are referenced relative to $\left(\mathrm{CDCl}_{3}\right)$ at $\delta=77.00 \mathrm{ppm}$ $\left({ }^{1} \mathrm{H}\right)$ and $\mathrm{C}_{6} \mathrm{D}_{6}$ at $\delta=128 \mathrm{ppm}$. Data for ${ }^{13} \mathrm{C}$ NMR are reported in terms of chemical shift. IR spectra were recorded on a ThermoFisher Nicolet iS10 spectrometer with Smart iTR diamond plate and are reported in terms of wavenumber of absorption $\left(\mathrm{cm}^{-1}\right)$.

\footnotetext{
${ }^{1}$ Tanaka, R.; Kawahara, T.; Shinto, Y.; Nakayama, Y.; Shiono, T. Macromolecules, 2017. 50, 5989-5993.

${ }^{2}$ Ziegler, K.; Gellert, H. G.; Martin, H.; Nagel, K.; Schneider, J. Justus Liebigs Ann. Chem. 1954, 589, 91-121.

${ }^{3}$ Perrin, D. D.; Armarego, W. L. F. Purification of Laboratory Chemicals. $3^{\text {rd }}$ ed., Pergamon Press, Oxford, 1988.

${ }^{4}$ Pangborn, A. B.; Giardello, M. A.; Grubbs, R. H.; Rosen, R. K.; Timmers, F. J. Organometallic. 1996, 15, 1518.
} 


\section{S2. Preparation of Vanadium Precatalysts}

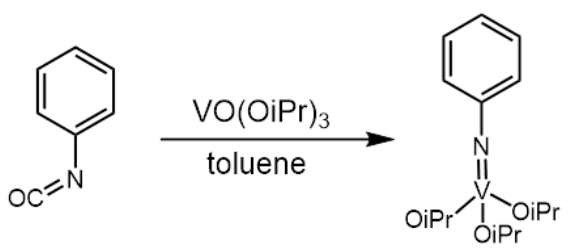

phenylimidovanadium (tris)isopropoxide (5) Phenyl isocyanate $(0.55 \mathrm{~mL}, 5.03 \mathrm{mmol})$ was added to a stirring solution of vanadium(V) oxytriisopropoxide $\left(\mathrm{VO}(\mathrm{OiPr})_{3}, \mathbf{6}\right)(1.19$ $\mathrm{ml}, 5.03 \mathrm{mmol})$ in toluene $(7 \mathrm{~mL})$. After refluxing overnight, the volatiles were removed in vacuo. Recrystallization from hexane at $-30{ }^{\circ} \mathrm{C}$ yielded orange-brown crystals. $(0.960 \mathrm{~g}$, $3.00 \mathrm{mmol}, 60 \%$ yield). ${ }^{1} \mathrm{H} \mathrm{NMR}\left(400 \mathrm{MHz}, \mathrm{CDCl}_{3}\right) \delta 7.14-7.25(\mathrm{~m}, 4 \mathrm{H}), 7.03(\mathrm{t}, \mathrm{J}=7.0$ $\mathrm{Hz}, 1 \mathrm{H}), 5.10-5.16(\mathrm{~m}, 3 \mathrm{H}), 1.36(\mathrm{~d}, \mathrm{~J}=6.2 \mathrm{~Hz}, 18 \mathrm{H}) .{ }^{13} \mathrm{C} \mathrm{NMR}\left(101 \mathrm{MHz}, \mathrm{CDCl}_{3}\right) \delta$ 128.5, 125.5, 125.0, 80.1, 26.5. Our ${ }^{1} \mathrm{H}$ - and ${ }^{13} \mathrm{C}-\mathrm{NMR}$ are consistent with those reported for this compound. ${ }^{5}$

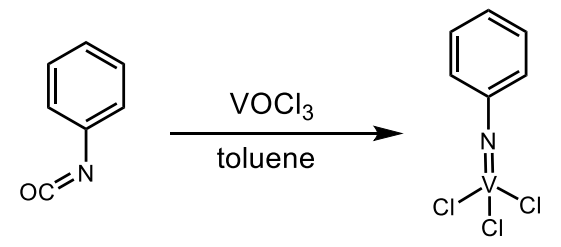

phenylimidovanadium trichloride (8). Phenyl isocyanate $(0.20 \mathrm{~mL}, 2.77 \mathrm{mmol})$ was added to a stirred solution of $\left[\mathrm{VOCl}_{3}\right](0.25 \mathrm{~mL}, 2.65 \mathrm{mmol})$ in toluene $(5 \mathrm{~mL})$. After refluxing overnight, the solvent was removed in vacuo. A purple crystalline solid was obtained (0.290 g, $1.17 \mathrm{mmol}, 45 \%$ yield). ${ }^{1} \mathrm{H}-\mathrm{NMR}\left(400 \mathrm{MHz}, \mathrm{CDCl}_{3}\right): \delta 7.59(\mathrm{~d}, 2 \mathrm{H})$, $7.58(\mathrm{t}, 2 \mathrm{H}), 7.38(\mathrm{~m}, 1 \mathrm{H}) .{ }^{13} \mathrm{C}-\mathrm{NMR}\left(101 \mathrm{MHz}, \mathrm{CDCl}_{3}\right): \delta 132.7,129.0,126.8$. Our ${ }^{1} \mathrm{H}-$ and ${ }^{13} \mathrm{C}-\mathrm{NMR}$ are consistent with those reported for this compound. ${ }^{6}$

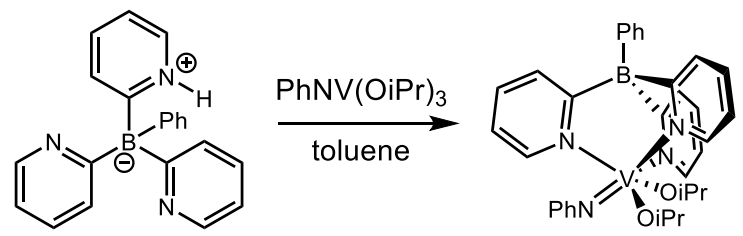

\footnotetext{
${ }^{5}$ Hagen, H.; Bezemer, C.; Boersma, J.; Kooijman, H.; Lutz, M.; Spek, A. L.; van Koten, G. Inorg. Chem. 2000, 39, 3970-3977.

${ }^{6}$ Zhang, S.; Nomura, K. J. Am. Chem. Soc. 2010, 132, 4960-4965
} 
TpyV(=NPh)(OiPr)2 (1). Vanadium phenylimido (tris)isopropoxide $(\mathbf{5}, 0.032 \mathrm{~g}, 0.10$ mmol) was added to a stirred solution of hydrogen phenyl tris(2-pyridyl)borate (TpyH, 4) $(0.032 \mathrm{~g}, 0.10 \mathrm{mmol})$ in toluene $(2 \mathrm{ml})$. After stirring overnight at room temperature, the volatiles were removed in vacuo, yielding an orange solid as the product $(0.058 \mathrm{~g}, 0.099$ mmol, 99\% yield). ${ }^{1} \mathrm{H}-\mathrm{NMR}\left(400 \mathrm{MHz}, \mathrm{C}_{6} \mathrm{D}_{6}\right): \delta 9.49$ (s, $\left.1 \mathrm{H}\right), 9.06$ (s, 2H), 8.22 (d, J = $6.6 \mathrm{~Hz}, 2 \mathrm{H}), 8.12(\mathrm{~d}, \mathrm{~J}=7.5 \mathrm{~Hz}, 1 \mathrm{H}), 7.71(\mathrm{~d}, \mathrm{~J}=7.5 \mathrm{~Hz}, 2 \mathrm{H}), 7.60(\mathrm{t}, \mathrm{J}=7.4 \mathrm{~Hz}, 2 \mathrm{H})$, $7.46(\mathrm{t}, \mathrm{J}=7.2 \mathrm{~Hz}, 1 \mathrm{H}), 6.96(\mathrm{~d}, \mathrm{~J}=8.2 \mathrm{~Hz}, 3 \mathrm{H}), 6.82-6.87(\mathrm{~m}, 4 \mathrm{H}), 6.66-6.71(\mathrm{~m}, 2 \mathrm{H})$, 6.32-6.36 (m, 2H), 6.11-6.20 (m, 2H), $1.79(\mathrm{~d}, \mathrm{~J}=5.9 \mathrm{~Hz}, 6 \mathrm{H}), 1.14(\mathrm{~d}, \mathrm{~J}=5.9 \mathrm{~Hz}, 6 \mathrm{H})$ ${ }^{13} \mathrm{C}-\mathrm{NMR}\left(101 \mathrm{MHz}, \mathrm{C}_{6} \mathrm{D}_{6}\right) \delta 151.6,150.3,137.1,134.9,131.2,125.6,125.1,118.2,83.9$, 26.9, 26.1. IR 2964, 1589, 1558, 1458, 1417, 1354, 1311, 1215, 1155, 1109, 1063, 1015, $965,883,838,759,742,712,683,648,635,625,602,563,463 \mathrm{~cm}^{-1}$. Elemental analysis data calculated for $\mathrm{C}_{33} \mathrm{H}_{36} \mathrm{BN}_{4} \mathrm{O}_{2} \mathrm{~V}$ : C $68.05 \%$, $\mathrm{H} 6.23 \%$, N 9.62\%; found: $\mathrm{C} 68.34 \%, \mathrm{H}$ $6.21 \%$, N 9.17\%; difference: C $+0.29 \%$, H $-0.02 \%$, N - $0.45 \%$. Single crystals for X-ray diffraction analysis were obtained by recrystallization in cold toluene solution.

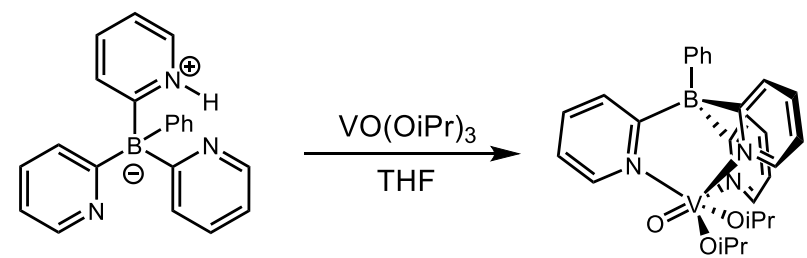

TpyV(O)(OiPr)2 (2). Vanadium(V) oxytriisopropoxide (VO(OiPr) 3 , 6) $(0.024 \mathrm{~mL}, 0.10$ mmol) was added to a stirred solution of hydrogen phenyl tris(2-pyridyl)borate (TpyH, 4) $(0.067 \mathrm{~g}, 0.10 \mathrm{mmol})$ in tetrahydrofuran $(2 \mathrm{ml})$. After stirring for 36 hours at room temperature, the volatiles were removed in vacuo. The resulting solid was rinsed with hexane and dried in vacuo, yielding green solid as the product $(0.050 \mathrm{~g}, 0.098 \mathrm{mmol}, 98 \%$ yield). ${ }^{1} \mathrm{H}-\mathrm{NMR}\left(400 \mathrm{MHz}, \mathrm{CDCl}_{3}\right): \delta 9.45(\mathrm{~d}, \mathrm{~J}=4.8 \mathrm{~Hz}, 2 \mathrm{H}), 8.86(\mathrm{~d}, \mathrm{~J}=4.3 \mathrm{~Hz}, 1 \mathrm{H})$, 7.86-7.95 (m, 3H), 7.39-7.49 (m, 8H), $7.03(\mathrm{~m}, 2 \mathrm{H}), 6.92(\mathrm{~m}, 1 \mathrm{H}), 5.88(\mathrm{~m}, \mathrm{~J}=5.8 \mathrm{~Hz}$, $2 \mathrm{H}), 1.54(\mathrm{~d}, \mathrm{~J}=5.9 \mathrm{~Hz}, 6 \mathrm{H}), 1.18(\mathrm{~d}, \mathrm{~J}=5.9 \mathrm{~Hz}, 6 \mathrm{H}) .{ }^{13} \mathrm{C}-\mathrm{NMR}\left(101 \mathrm{MHz}, \mathrm{CDCl}_{3}\right) \delta$ $150.5,150.3,138.0,136.9,135.7,135.1,131.3,129.1,128.3,127.5,125.4,125.0,118.8$, 118.7, 86.1, 25.3, 25.0 IR 2965, 1591, 1559, 1460, 1417, 1358, 1318, 1156, 1101, 1066, 
$1015,945,909,882,845,762,751,732,710,637,612,467,452 \mathrm{~cm}^{-1}$. Elemental analysis data calculated for $\mathrm{C}_{27} \mathrm{H}_{31} \mathrm{BN}_{3} \mathrm{O}_{3} \mathrm{~V}$ : C $63.92 \%, \mathrm{H} 6.16 \%, \mathrm{~N} 8.28$; \%; found: $\mathrm{C} 62.76 \%, \mathrm{H}$ $5.80 \%$, N 8.43\%; difference C $-1.16 \%$, H $-0.36 \%, \mathrm{~N}+0.15 \%$.

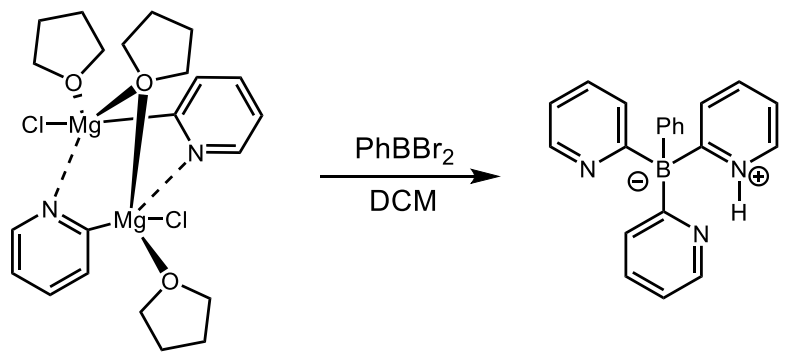

Phenyl tris(2-pyridyl)borate (TpyH, 4). Synthesis of hydrogen phenyl tris(2pyridyl)borate was based on the reported synthesis of hydrogen 4-t-butylphenyl tris(2pyridyl)borate. ${ }^{7}$ Phenyl dibromoborane $(0.134 \mathrm{~g}, 0.54 \mathrm{mmol})$ in dichloromethane $(1 \mathrm{~mL})$ was added dropwise to a solution of 2-pyridylmagnesium chloride : tetrahydrofuran complex $(2: 3)^{7}(0.407 \mathrm{~g}, 0.81 \mathrm{mmol})$ in dichloromethane $(4 \mathrm{~mL})$. The resulting dark red mixture was kept stirring for 5 hours. The reaction mixture was poured into an aqueous $\mathrm{Na}_{2} \mathrm{CO}_{3}$ solution to give a slurry which was stirred for 30 minutes. Extraction with dichloromethane gave a brown organic phase that was dried over $\mathrm{Na}_{2} \mathrm{SO}_{4}$. The volatiles were removed under vacuum to give an oil that was redissolved in acetone, filtered, and evaporated to dryness. The product was further purified by flash chromatography on silica gel with a gradient mixture of hexanes and acetone containing $1 \%(\mathrm{v} / \mathrm{v})$ triethylamine as the eluent. The product was obtained as a white solid by drying under vacuum $(0.088 \mathrm{~g}$, $0.27 \mathrm{mmol}, 50 \%$ yield). ${ }^{1} \mathrm{H}-\mathrm{NMR}\left(400 \mathrm{MHz}, \mathrm{CDCl}_{3}\right) \delta 8.50$ (d, J = 5.0 Hz, 3H), 7.60 (t, J $=7.5 \mathrm{~Hz}, 3 \mathrm{H}), 7.40(\mathrm{~d}, \mathrm{~J}=7.8 \mathrm{~Hz}, 3 \mathrm{H}), 7.07-7.14(\mathrm{~m}, 8 \mathrm{H}) .{ }^{13} \mathrm{C}-\mathrm{NMR}\left(101 \mathrm{MHz}, \mathrm{CDCl}_{3}\right)$ $\delta$ 143.4, 136.4, 134.9, 131.7, 127.2, 124.6, 119.9. IR 2527, 2160, 2030, 1622, 1581, 1571, $1555,1524,1451,1384,1239,1150,1091,1008,869,751,706,647,635,624,610,486$,

${ }^{7}$ Cui, C.; Lalancette, R. A.; Jäkle, F. Chem. Commun., 2012, 48, 6930-6932 
470, 460, $420 \mathrm{~cm}^{-1}$. Elemental analysis data calculated for $\mathrm{C}_{21} \mathrm{H}_{18} \mathrm{BN}_{3}: \mathrm{C} 78.04 \%, \mathrm{H} \mathrm{5.61 \%}$, N 13.00\%; found: C 77.89, H 5.30, N 12.93\%; difference C - $0.15 \%, \mathrm{H}-0.31 \%, \mathrm{~N}-0.07 \%$.

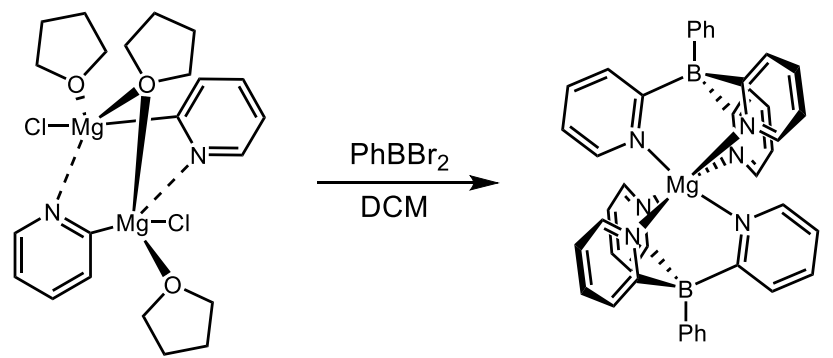

Bis(phenyl tris(2-pyridyl)borate) Magnesium (Tpy2Mg, 7). Synthesis of bis(phenyl tris(2-pyridyl)borate) magnesium was based on the reported synthesis of magnesium bis(4t-butylphenyl tris(2-pyridyl)borate). ${ }^{7}$ Phenyl dibromoborane $(0.408 \mathrm{~g}, 1.65 \mathrm{mmol})$ in dichloromethane $(2 \mathrm{~mL})$ was added dropwise to a solution of 2-pyridylmagnesium chloride : tetrahydrofuran complex (2 : 3) (1.215 g, $2.27 \mathrm{mmol})$ in DCM (5 mL). The resulting dark red mixture was kept stirring for 5 hours. The reaction mixture was poured into an aqueous $\mathrm{Na}_{2} \mathrm{CO}_{3}$ solution to give a slurry which was stirred for 30 minutes. Extraction with DCM gave a brown organic phase that was dried over $\mathrm{Na}_{2} \mathrm{SO}_{4}$. The volatiles were removed under vacuum to give an oil that was redissolved in acetone. The product was collected by filtration, washed with acetone, and then dried under vacuum. Yield: $0.025 \mathrm{~g}, 0.037 \mathrm{mmol}$, 45 \%). ${ }^{1} \mathrm{H}$ NMR (400 MHz, $\left.\mathrm{CDCl}_{3}\right) \delta 8.04(\mathrm{~d}, \mathrm{~J}=5.7 \mathrm{~Hz}, 2 \mathrm{H}), 7.66(\mathrm{~d}, \mathrm{~J}=8.0 \mathrm{~Hz}, 3 \mathrm{H})$, 7.51-7.56 (m, 5H), $7.38(\mathrm{t}, \mathrm{J}=6.6 \mathrm{~Hz}, 4 \mathrm{H}), 6.64(\mathrm{t}, \mathrm{J}=6.2 \mathrm{~Hz}, 3 \mathrm{H}) .{ }^{13} \mathrm{C}$ NMR $(101 \mathrm{MHz}$, $\left.\mathrm{CDCl}_{3}\right) \delta 148.3,137.3,134.9,129.7,127.4,124.8,118.6$. IR 1723, 1587, 1557, 1456, 1417 , 1154, 1089, 1058, 1013, 874, 739, 709, 649, 634, 625, $420 \mathrm{~cm}^{-1}$. Elemental analysis calculated for $\mathrm{C}_{42} \mathrm{H}_{34} \mathrm{~B}_{2} \mathrm{MgN}_{6}$ : C 75.44\% H 5.13\%, N 12.57\%; found C 74.35, H 5.8\%, N $12.32 \%$; difference: $\mathrm{C}-1.09 \%, \mathrm{H}+0.67 \%, \mathrm{~N}-0.25 \%$. 


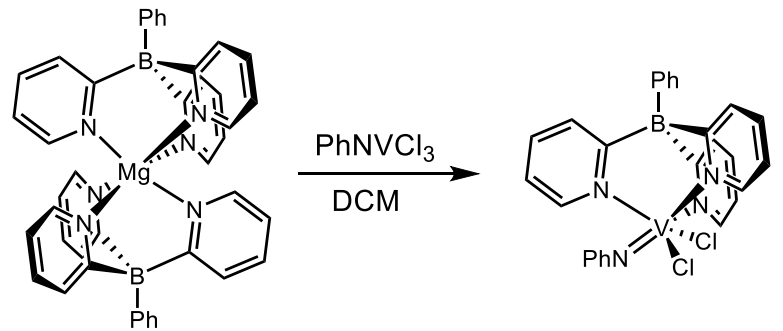

TpyV(=NPh)Cl2 (3). Vanadium phenylimido trichloride (0.050 g, $0.20 \mathrm{mmol})$ was added to a stirred solution of $\mathrm{Tpy}_{2} \mathrm{Mg}(7,0.067 \mathrm{~g}, 0.10 \mathrm{mmol})$ in dichloromethane $(2 \mathrm{ml})$. After stirring overnight at room temperature, the resulting mixture was filtered. The filtrate was dried in vacuo, yielding the product as a dark brown solid ( $0.096 \mathrm{~g}, 0.18 \mathrm{mmol}, 90 \%$ yield). ${ }^{1} \mathrm{H}-\mathrm{NMR}\left(400 \mathrm{MHz}, \mathrm{CDCl}_{3}\right): \delta 9.32(\mathrm{~d}, \mathrm{~J}=4.8 \mathrm{~Hz}, 1 \mathrm{H}), 9.14(\mathrm{~d}, \mathrm{~J}=5.0 \mathrm{~Hz}, 2 \mathrm{H}), 7.89$ $7.96(\mathrm{~m}, 3 \mathrm{H}), 7.73(\mathrm{~d}, \mathrm{~J}=7.5 \mathrm{~Hz}, 2 \mathrm{H}), 7.39-7.52(\mathrm{~m}, 10 \mathrm{H}), 7.28(\mathrm{~m}, 1 \mathrm{H}), 7.08(\mathrm{~m}, 1 \mathrm{H})$, $6.89(\mathrm{~m}, 2 \mathrm{H}) .{ }^{13} \mathrm{C}-\mathrm{NMR}\left(101 \mathrm{MHz}, \mathrm{CDCl}_{3}\right) \delta 158.7,152.9,152.4,137.7,136.7,136.2$, 132.6, 131.4, 130.7, 129.0, 127.9, 125.6, 119.6, 118.5. IR 1592, 1556, 1458, 1416, 1267 , $1218,1159,1093,1065,1015,946,908,883,847,763,740,710,682,657,636,626,564$, $469,436,409 \mathrm{~cm}^{-1}$. Elemental analysis data calculated for $\mathrm{C}_{27} \mathrm{H}_{22} \mathrm{BCl}_{2} \mathrm{~N}_{4} \mathrm{~V}: \mathrm{C} 60.60 \%, \mathrm{H}$ 4.14\%, N 10.47\%; found: C 57.92, H 4.10, N 9.42\%; difference: C -2.68\%, H -0.04\%, N $1.05 \%$. 


\section{S3. Spectral Data for Vanadium Precatalysts \\ TpyV(=NPh)(OiPr) 2 (1)}

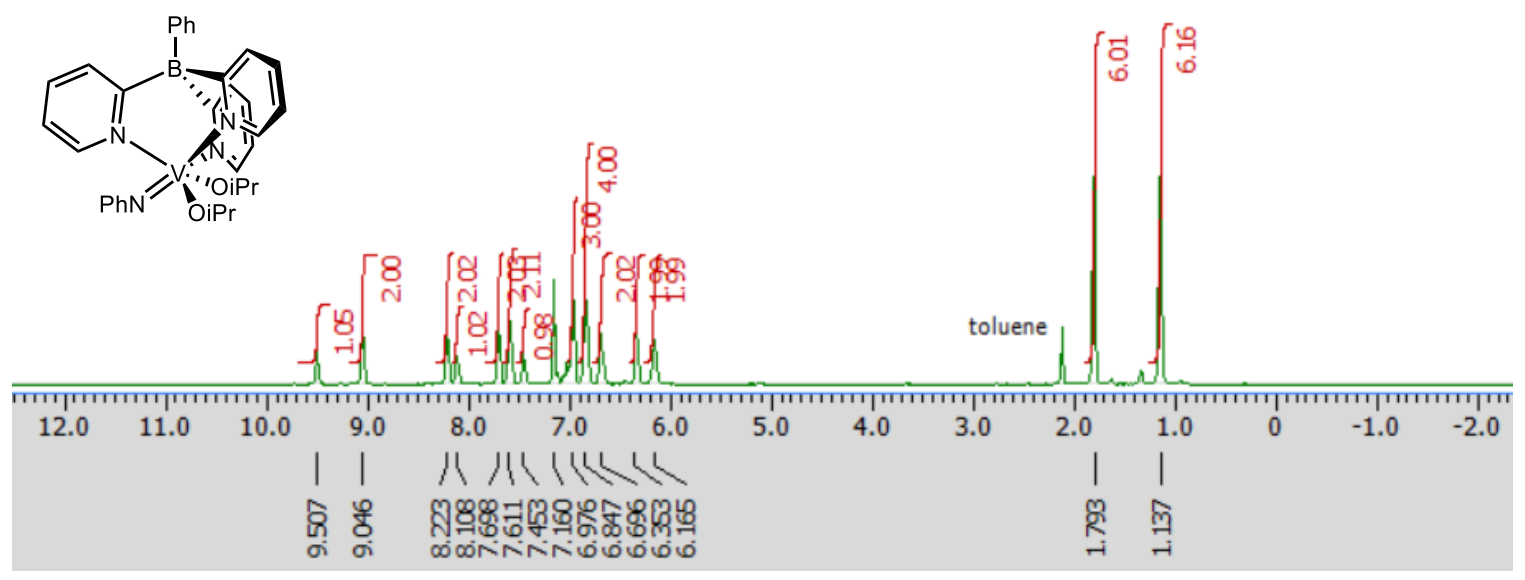

Figure S1.1. ${ }^{1} \mathrm{H}-\mathrm{NMR}$ spectrum of $\mathrm{TpyV}(=\mathrm{NPh})(\mathrm{OiPr})_{2}, \mathrm{C}_{6} \mathrm{D}_{6}, 400 \mathrm{MHz}$.

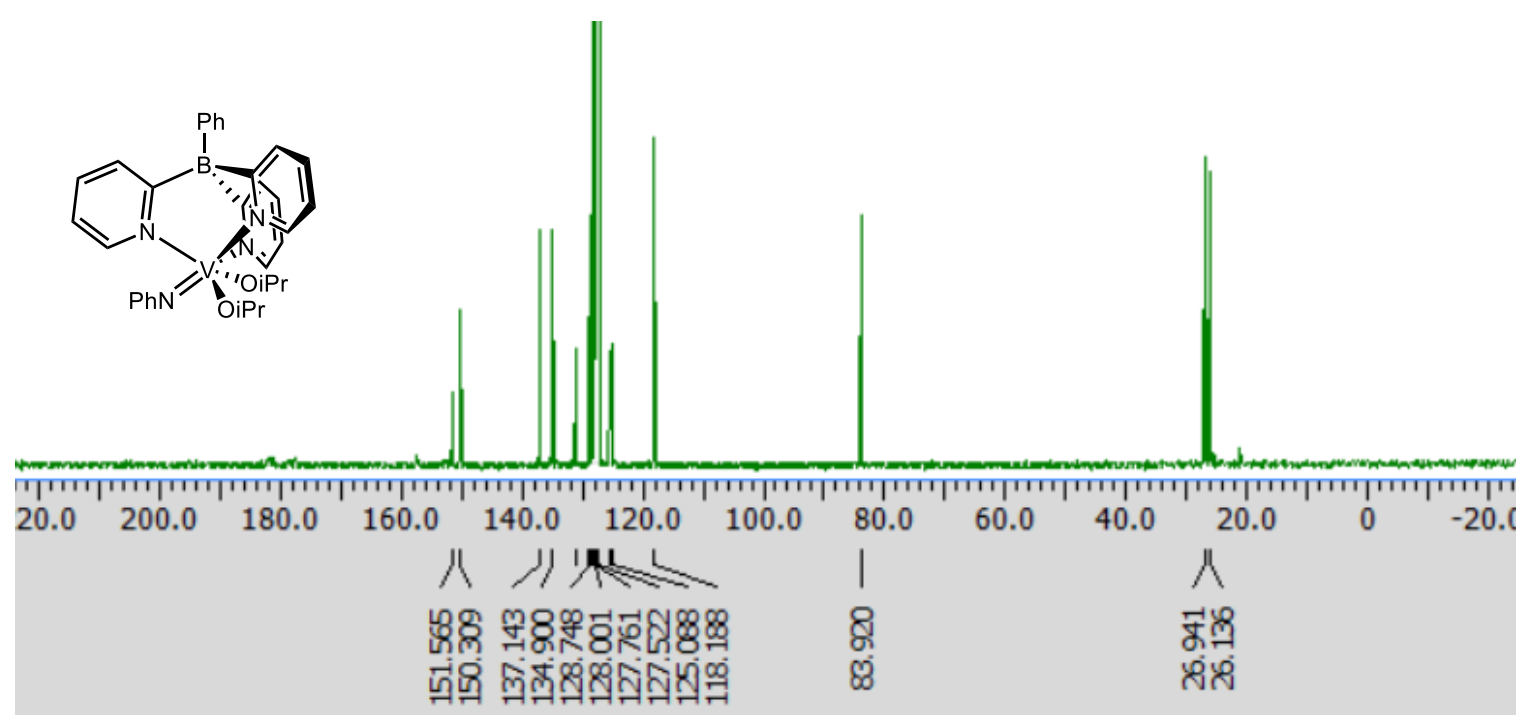

Figure S1.2. ${ }^{13} \mathrm{C}-\mathrm{NMR}$ spectrum of $\mathrm{TpyV}(=\mathrm{NPh})(\mathrm{OiPr})_{2}, \mathrm{C}_{6} \mathrm{D}_{6}, 101 \mathrm{MHz}$. 


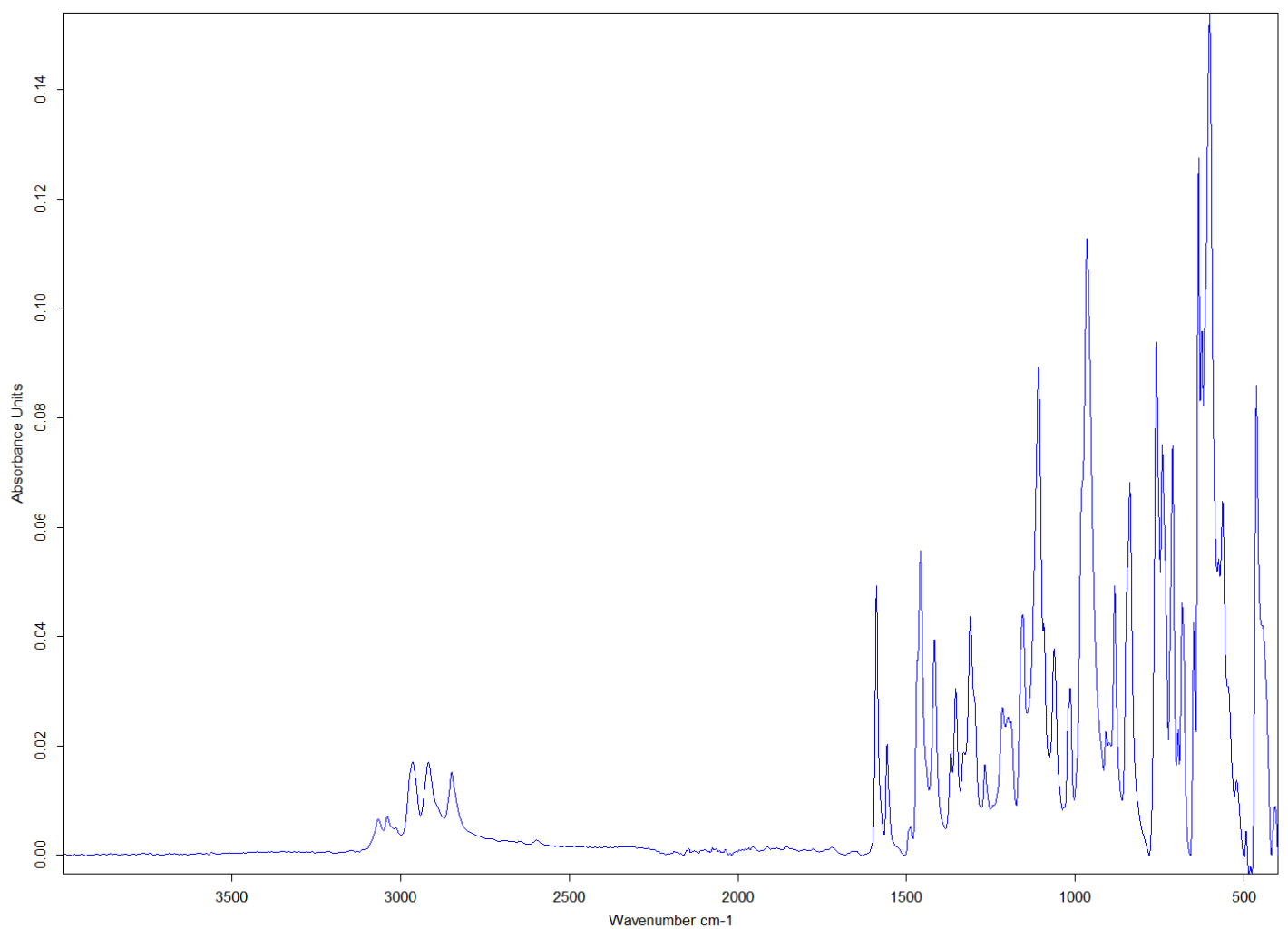

Figure S1.3. IR spectrum of $\mathrm{TpyV}(=\mathrm{NPh})(\mathrm{OiPr})_{2}$, diamond ATR. 


\section{$\operatorname{TpyV}(0)(O i P r) 2(2)$}

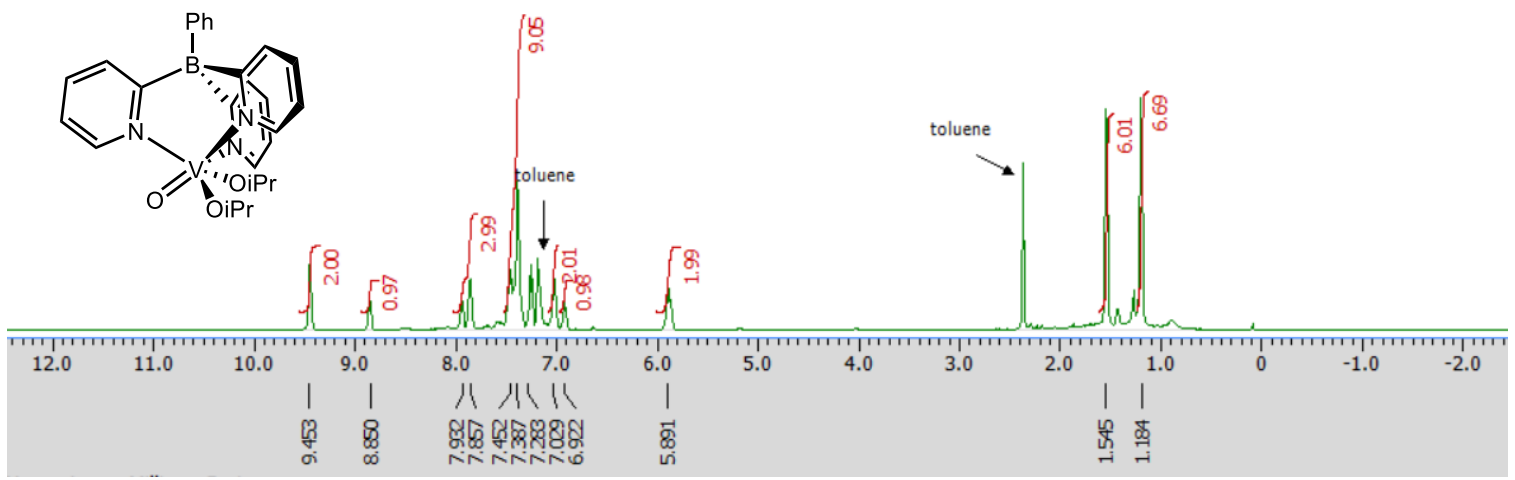

Figure S1.4. ${ }^{1} \mathrm{H}-\mathrm{NMR}$ spectrum of $\mathrm{Tpy}(\mathrm{O})(\mathrm{OiPr})_{2}, \mathrm{CDCl}_{3}, 400 \mathrm{MHz}$.

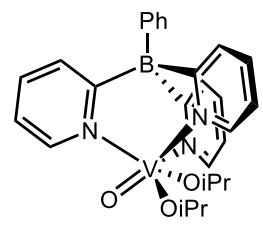

Figure S1.5. ${ }^{13} \mathrm{C}-\mathrm{NMR}$ spectrum of $\mathrm{Tpy} \mathrm{V}(\mathrm{O})(\mathrm{OiPr})_{2}, \mathrm{CDCl}_{3}, 101 \mathrm{MHz}$. 
$S 12$

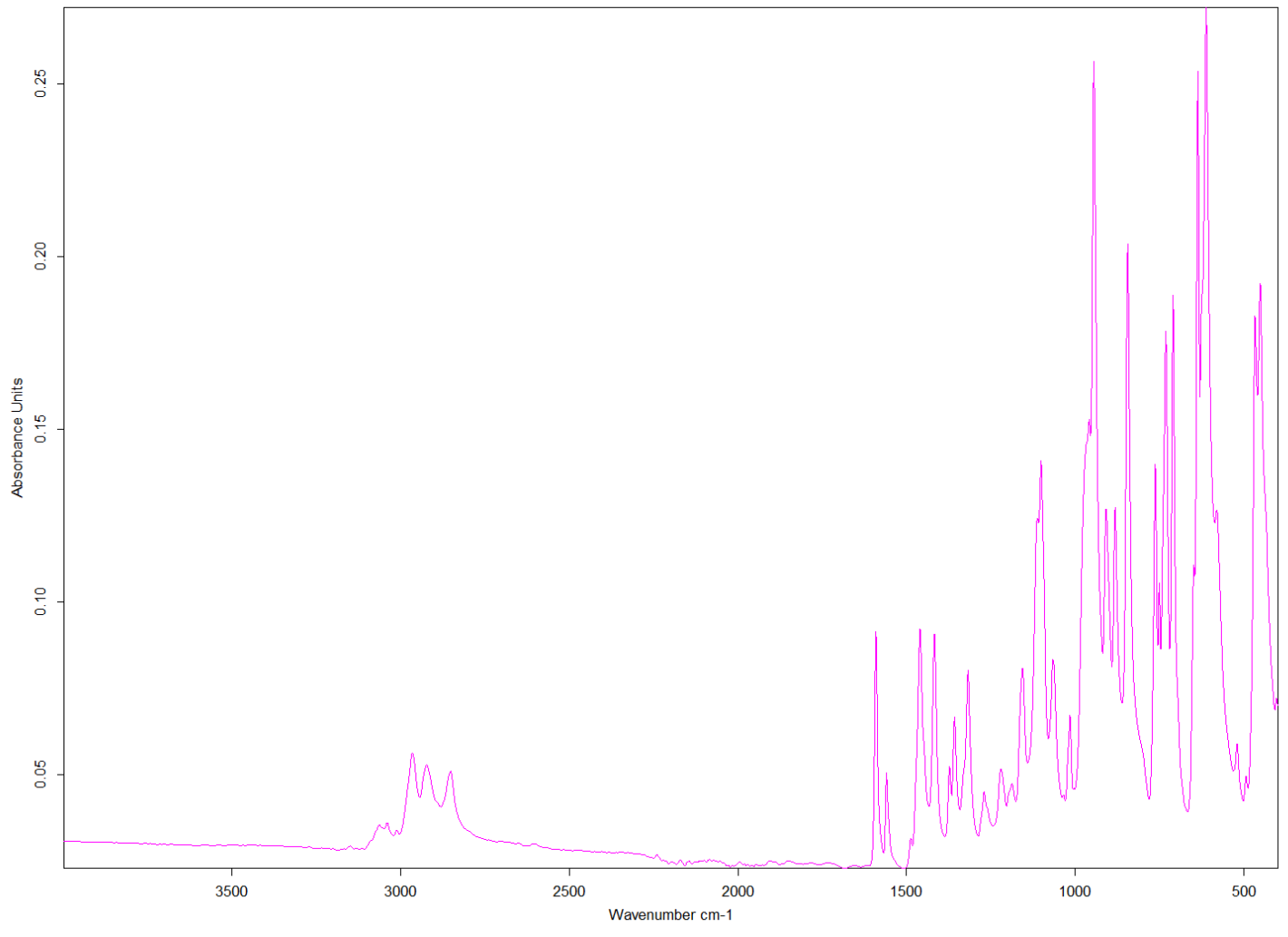

Figure S1.6. IR spectrum of $\mathrm{TpyV}(\mathrm{O})(\mathrm{OiPr})_{2}$, diamond ATR. 


\section{$\operatorname{TpyV}(=\mathrm{NPh}) \mathrm{Cl}_{2}(3)$}

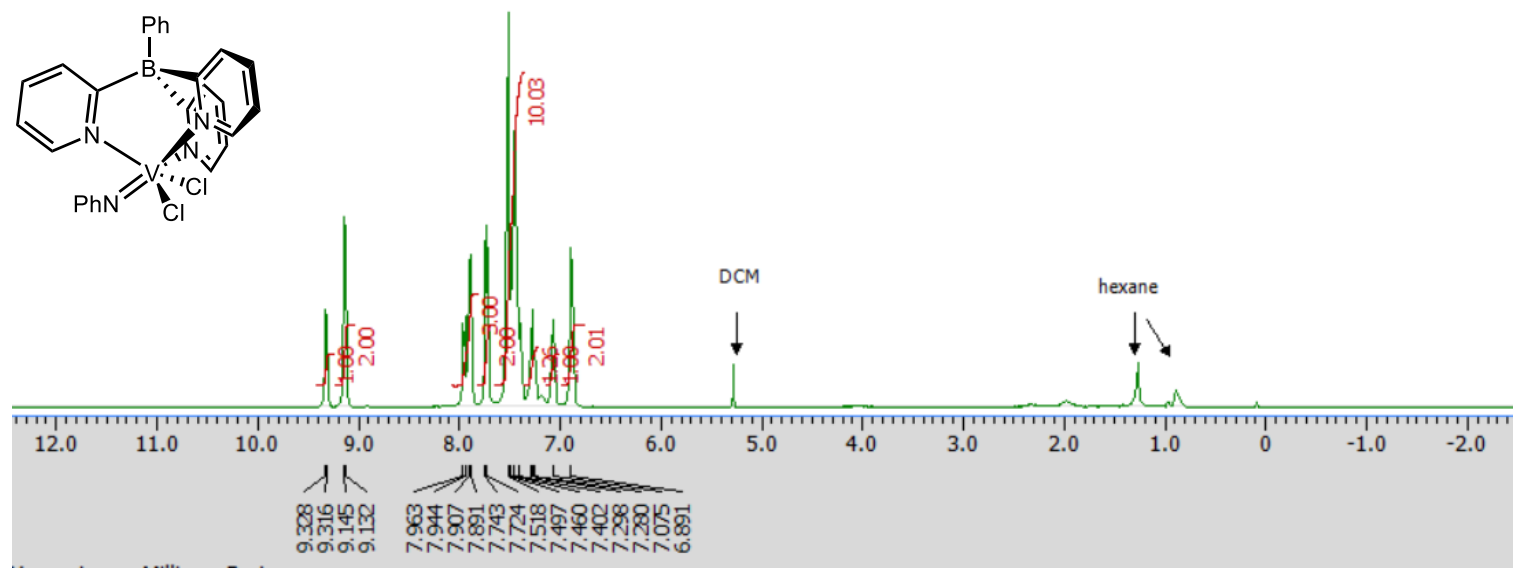

Figure S1.7. ${ }^{1} \mathrm{H}-\mathrm{NMR}$ spectrum of $\mathrm{TpyV}(=\mathrm{NPh}) \mathrm{Cl}_{2}, \mathrm{CDCl}_{3}, 400 \mathrm{MHz}$.

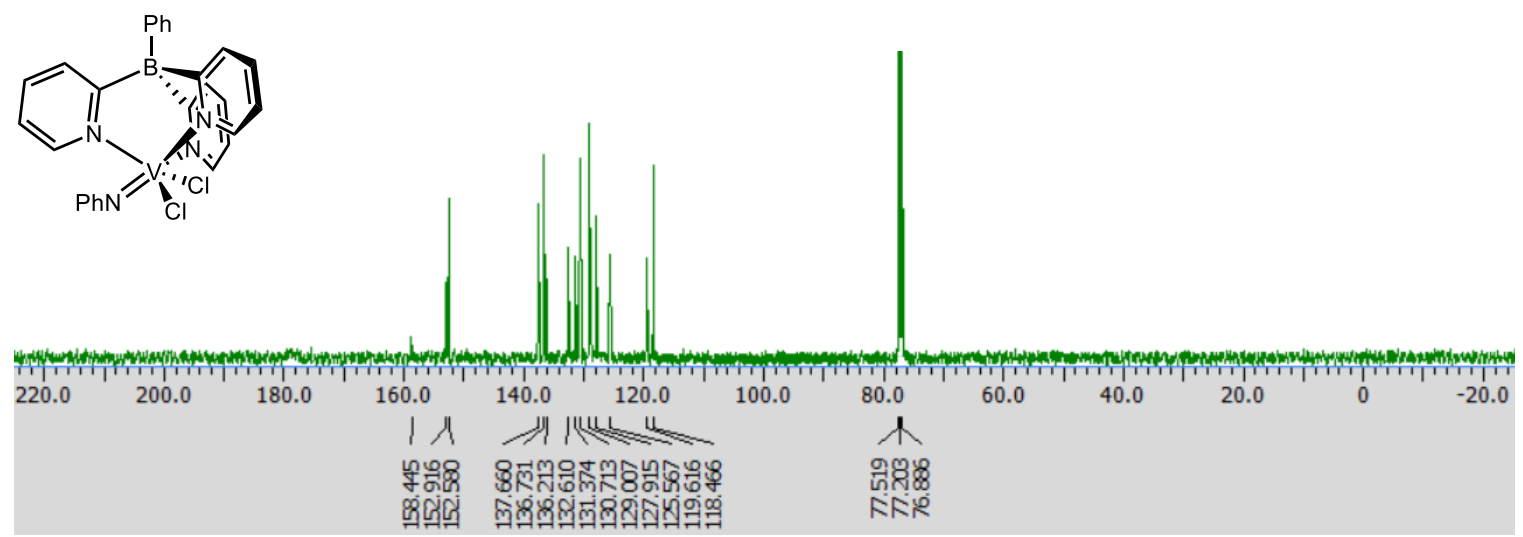

Figure S1.8. ${ }^{13} \mathrm{C}-\mathrm{NMR}$ spectrum of $\mathrm{TpyV}(=\mathrm{NPh}) \mathrm{Cl}_{2}, \mathrm{CDCl}_{3}, 101 \mathrm{MHz}$. 


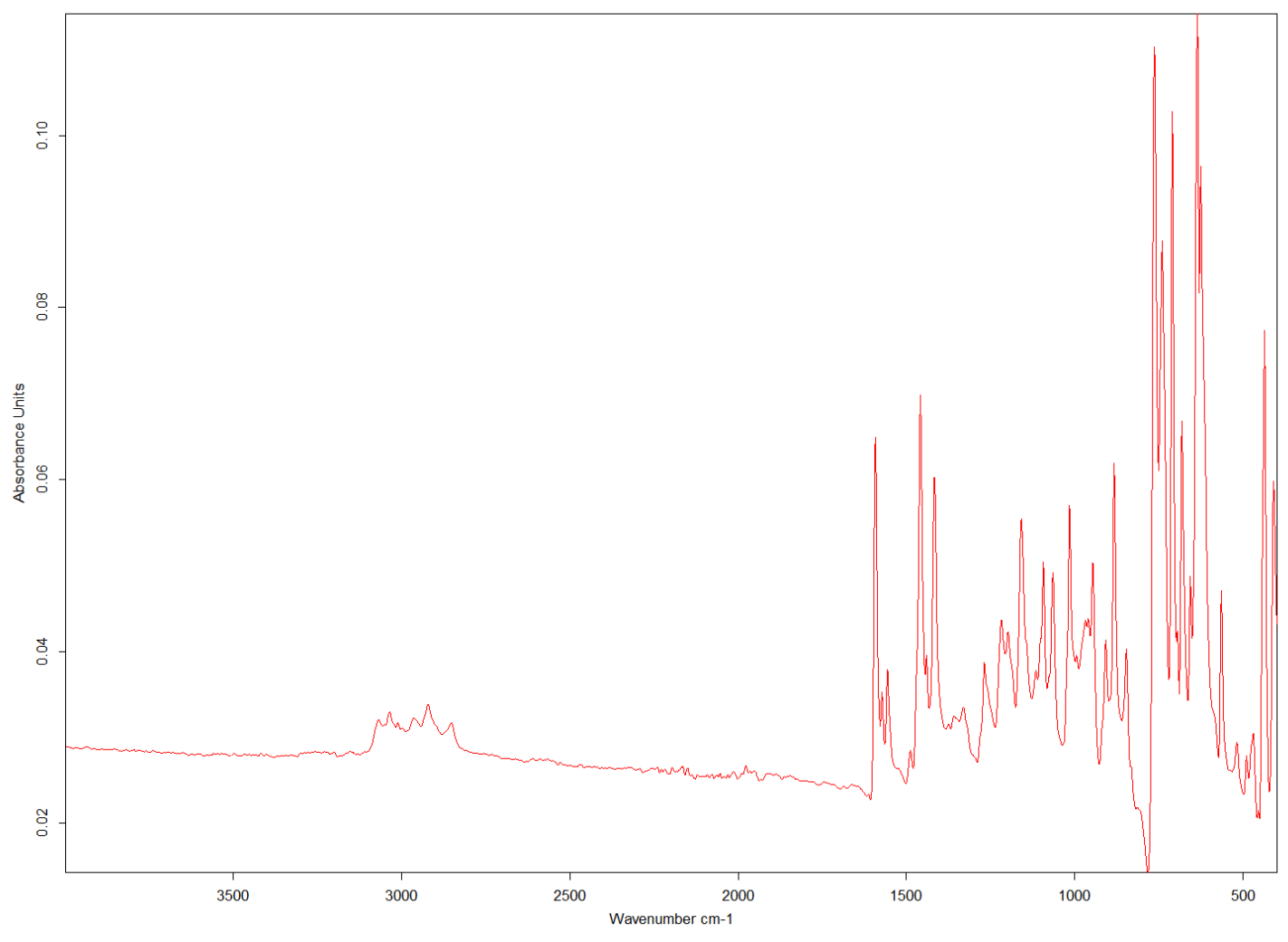

Figure S1.9. IR spectrum of $\mathrm{TpyV}(=\mathrm{NPh}) \mathrm{Cl}_{2}$, diamond ATR. 


\section{ТруН (4)}<smiles></smiles>

Figure S1.10. ${ }^{1} \mathrm{H}-\mathrm{NMR}$ spectrum of $\mathrm{TpyH}, \mathrm{CDCl}_{3}, 400 \mathrm{MHz}$.

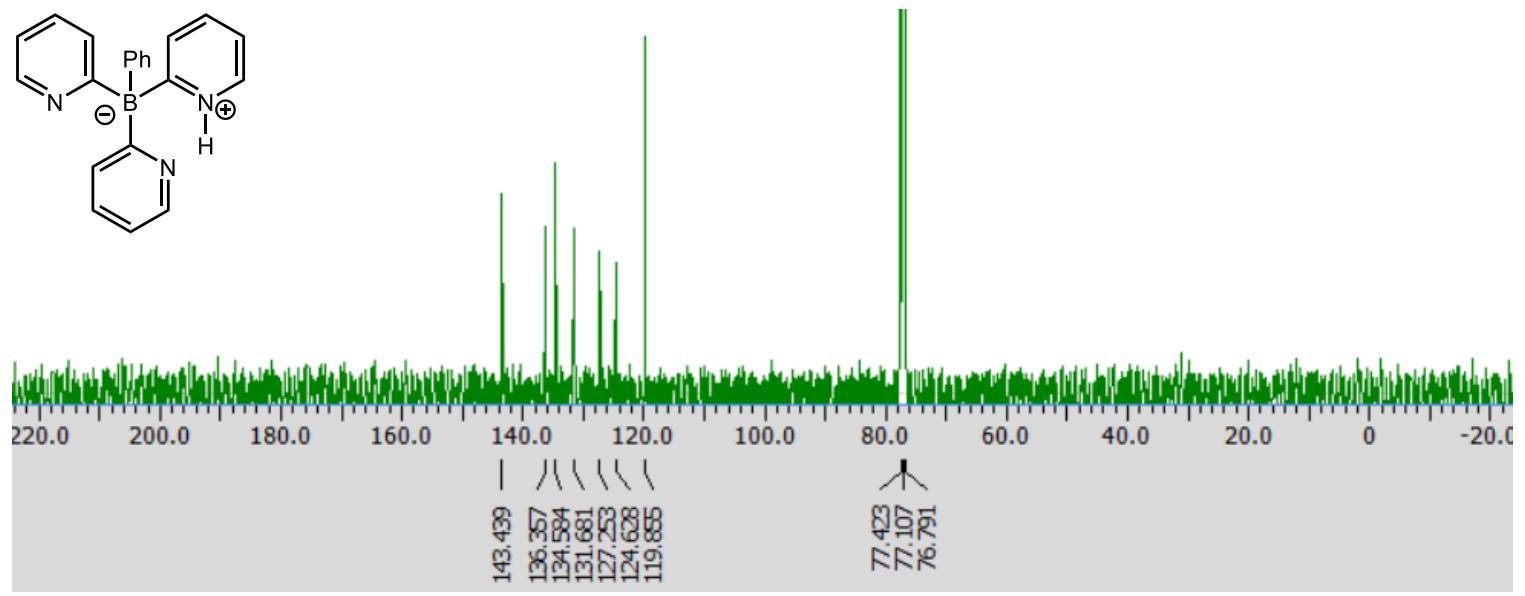

Figure S1.11. ${ }^{13} \mathrm{C}-\mathrm{NMR}$ spectrum of TpyH, $\mathrm{CDCl}_{3}, 101 \mathrm{MHz}$. 
C:IUsersIDr.Comito GrouplDesktoplJinIJQ-TpyH.0

1/6/2021 5:41:22 PN

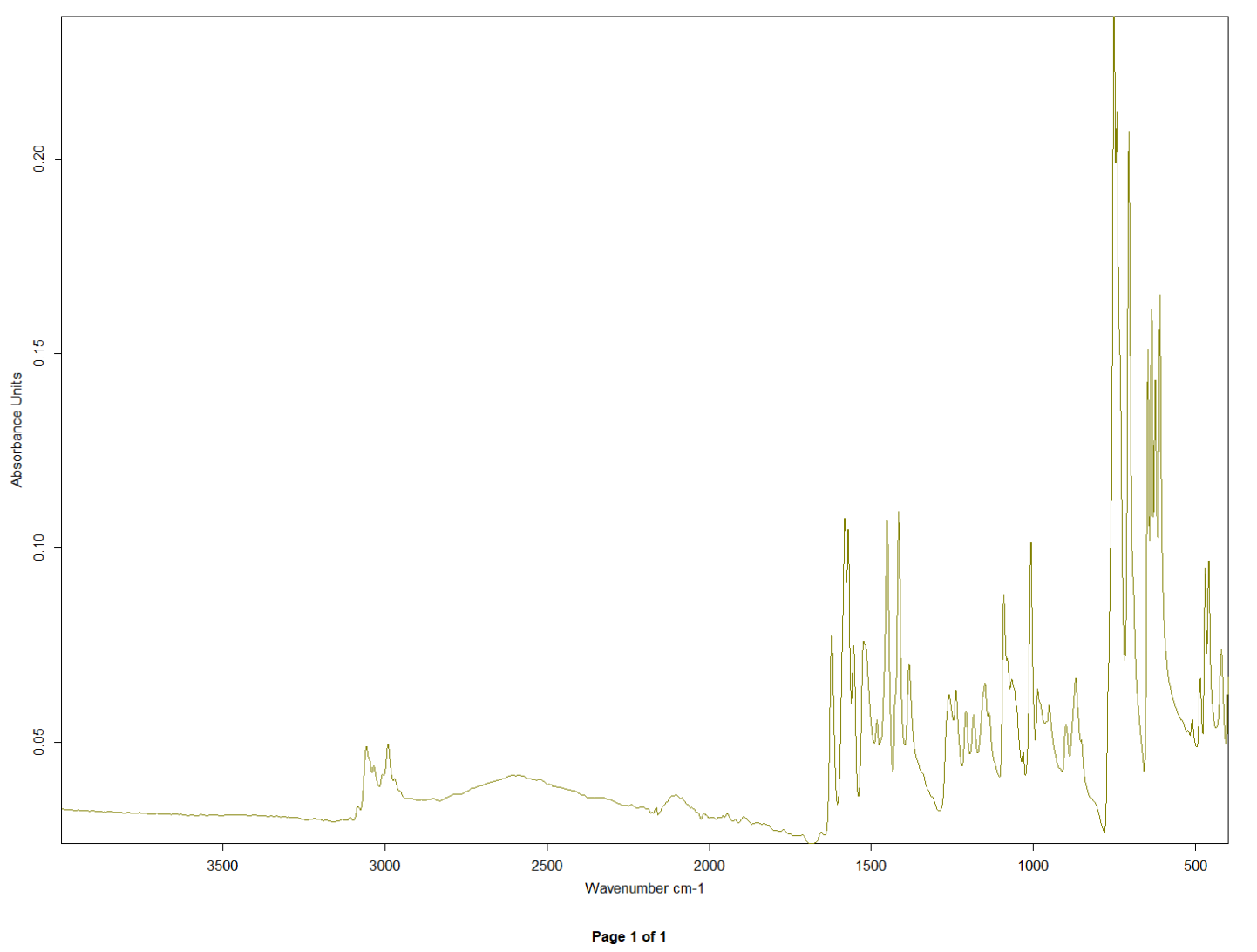

Figure S1.12. IR spectrum of TpyH, diamond ATR. 


\section{$\operatorname{Tpy}_{2} M g(7)$}

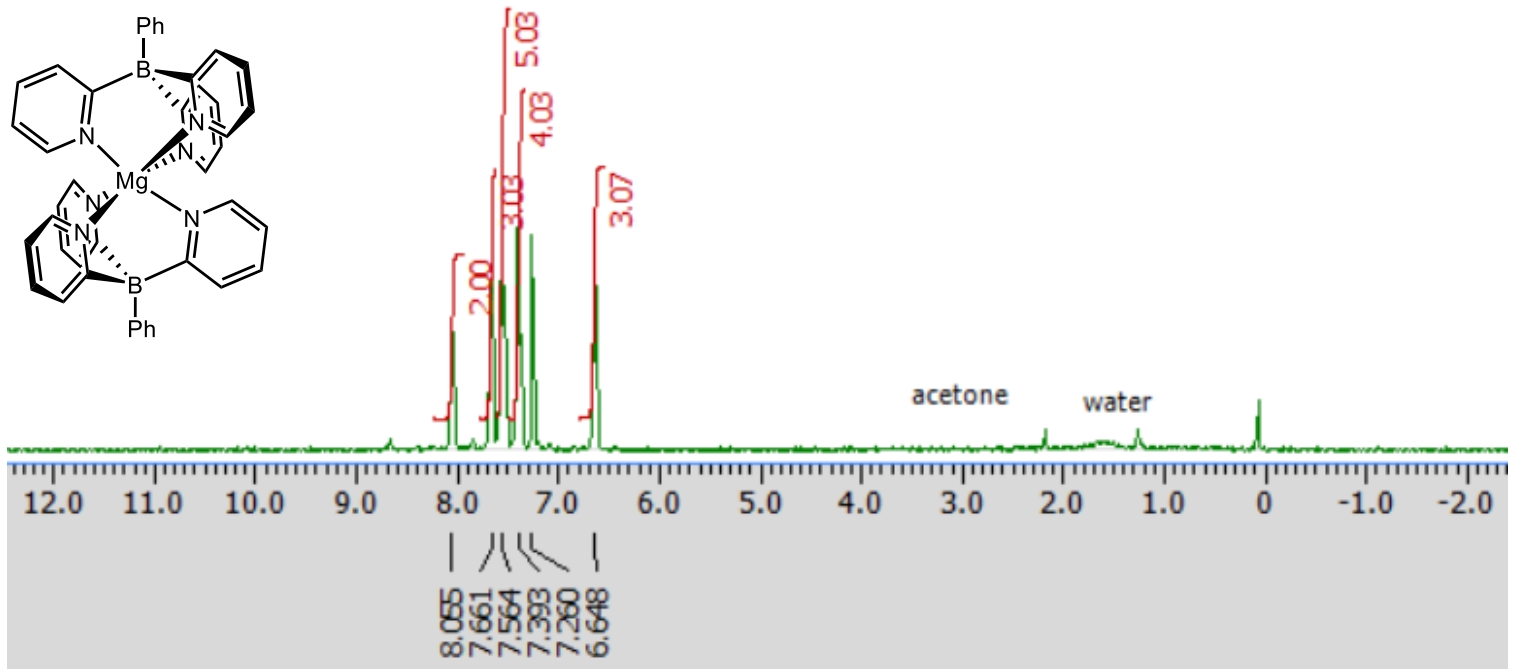

Figure S1.13. ${ }^{1} \mathrm{H}-\mathrm{NMR}$ spectrum of $\mathrm{Tpy}_{2} \mathrm{Mg}, \mathrm{CDCl}_{3}, 400 \mathrm{MHz}$.

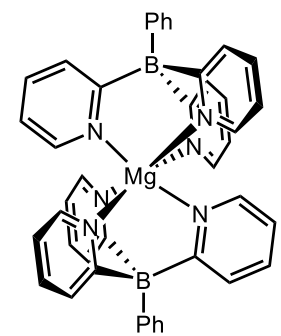

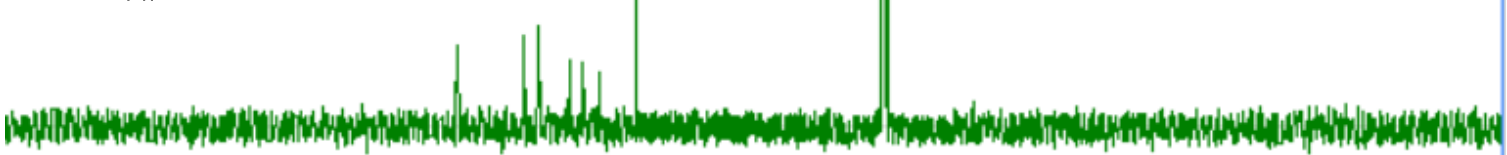

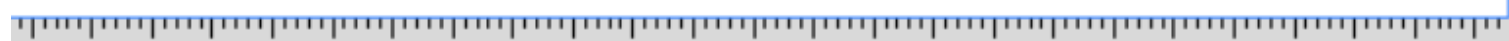

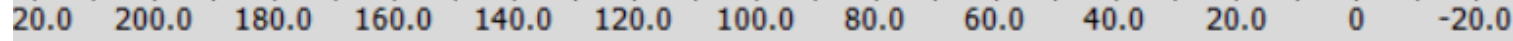
| 川小! A

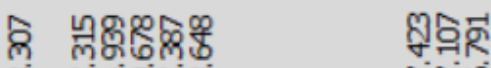

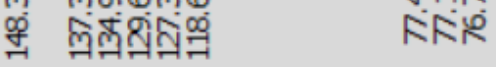

Figure S1.14. ${ }^{13} \mathrm{C}-\mathrm{NMR}$ spectrum of $\mathrm{Tpy}_{2} \mathrm{Mg}, \mathrm{CDCl}_{3}, 101 \mathrm{MHz}$. 


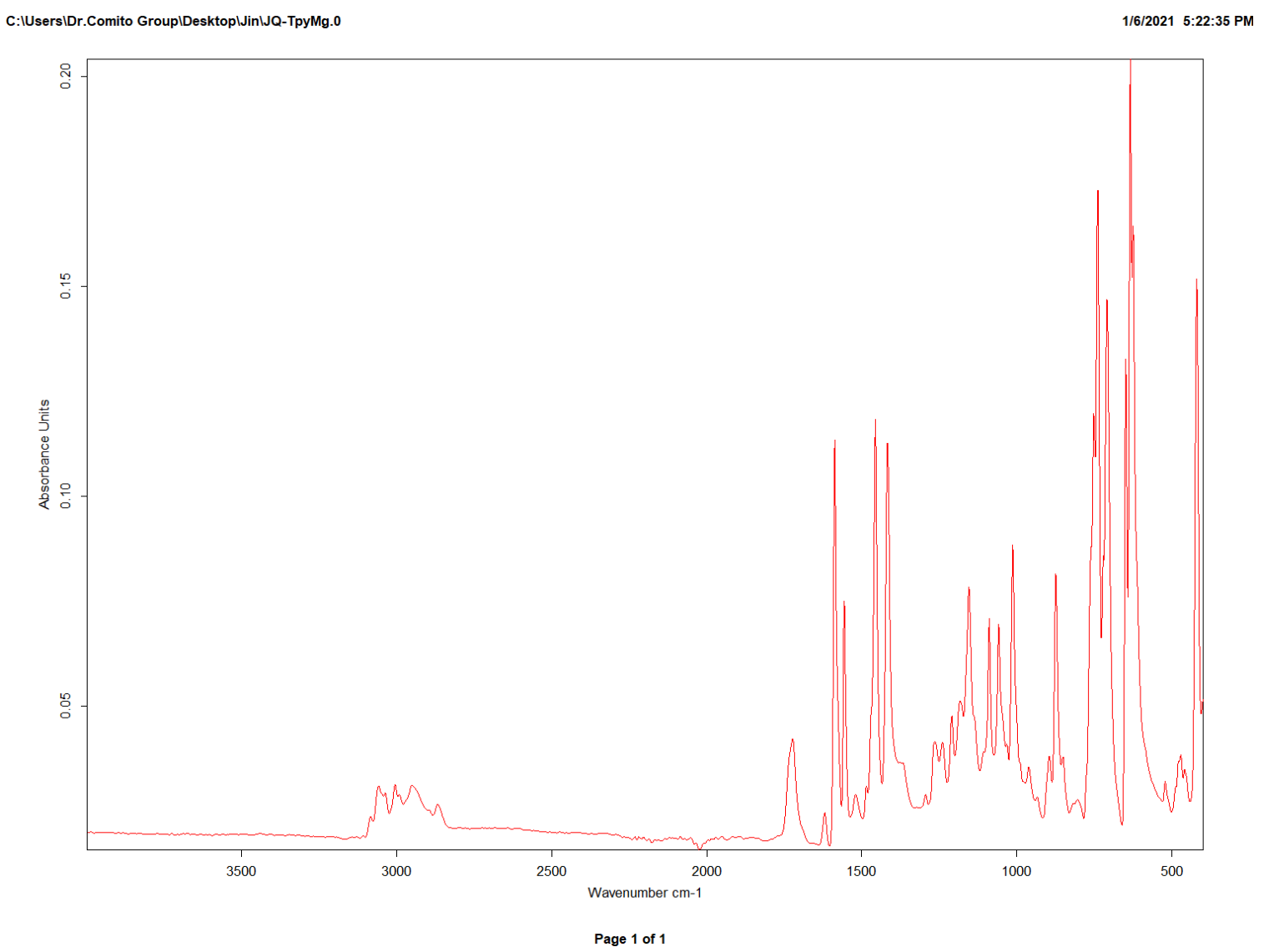

Figure S1.15. IR spectrum of $\mathrm{Tpy}_{2} \mathrm{Mg}$, diamond ATR. 


\section{S4. X-ray Structure determination of $\mathrm{TpyV}(=\mathrm{NPh})(\mathrm{OiPr})_{2}(1)$}

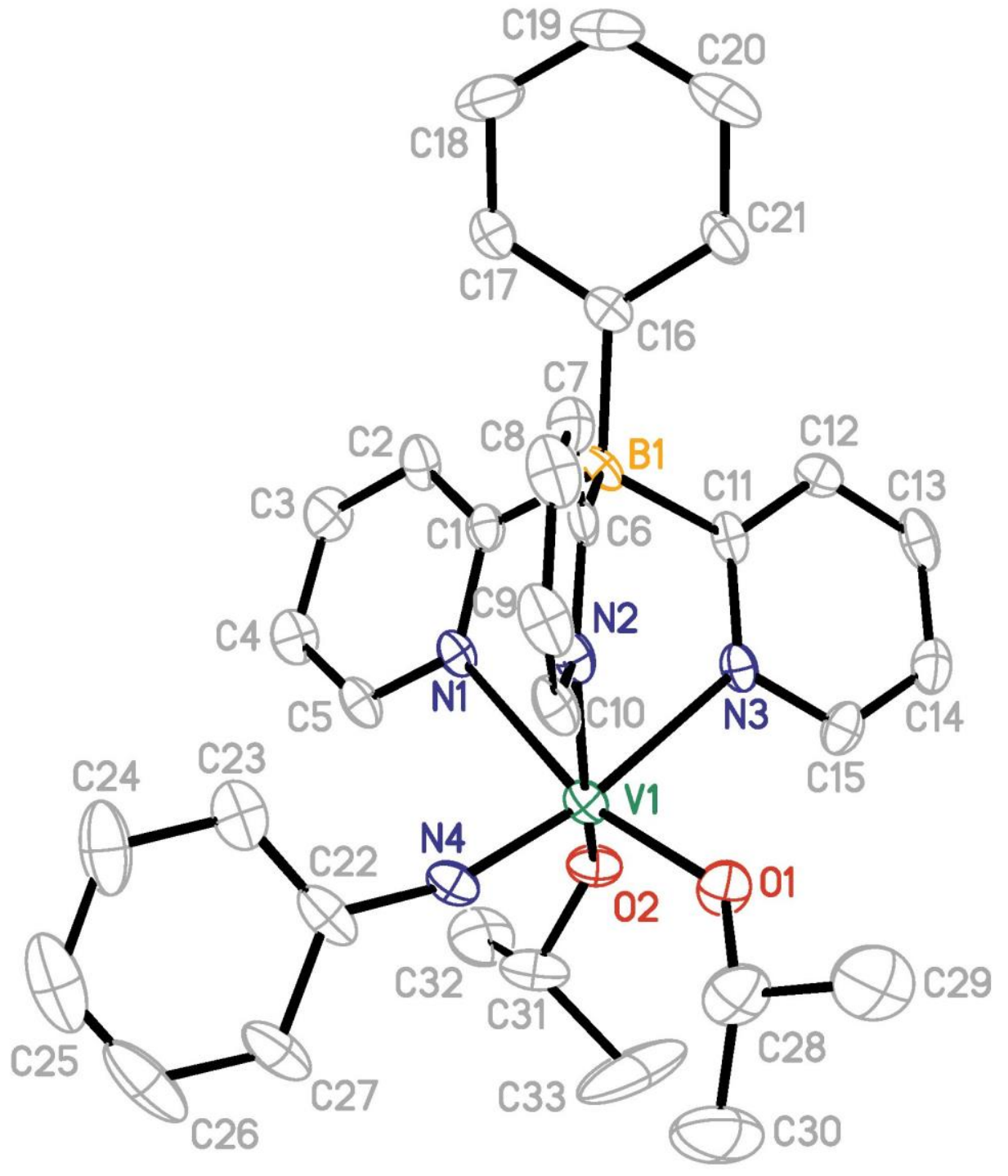

Figure S2. View of $\operatorname{TpyV}(=\mathrm{NPh})(\mathrm{OiPr})_{2}(\mathbf{1})$ showing the atom numbering scheme. Thermal ellipsoids are $50 \%$ equiprobability envelopes, with hydrogens omitted. 
All measurements were made with a Bruker DUO platform diffractometer equipped with a 4K CCD APEX II detector and an Incoatec 30 Watt $\mathrm{Cu}$ microsource with compact multilayer optics. A segment of data (4140 frames at $4 \mathrm{~cm}$ detector distance) was collected using a narrow-frame algorithm with scan widths of 0.50 deg in omega and an exposure time of $20 \mathrm{~s} /$ frame. The data collection crystal was found to be a two-domain twin, approximately 50:50, with the two separate domains related to each other by a 180 degree

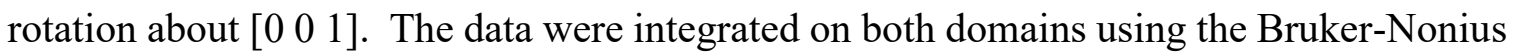
SAINT program, with the intensities corrected for Lorentz factor, polarization, air absorption, and absorption due to variation in the path length through the detector faceplate. The data were scaled, and an absorption correction was applied using TWINABS. Redundant reflections were averaged. Final cell constants were refined using 8127 reflections having I $>10$ sigma(I), and these, along with other information pertinent to data collection and refinement, are listed in Table S4.1. The Laue symmetry was determined to be $2 / \mathrm{m}$, and from the systematic absences noted the space group was shown unambiguously to be $\mathrm{P} 2(1) / \mathrm{c}$. The asymmetric unit consists of two independent organometallic complexes and four molecules of toluene solvent. Three of the four toluene sites were found to be disordered, two having two slightly different orientations and one having three quite different orientations. All disordered groups were refined using ideal rigid body models. Occupancy factors were estimated based on comparison of the isotropic displacement parameters for each group. Several structure factors which were obviously miscalculated during the twin analysis were omitted from the final refinement. 
Table S1.1 Crystal data and structure refinement for TpyV(=NPh)(OiPr)2 (1)

\begin{tabular}{|c|c|}
\hline Identification code & TpyV(=NPh)(OiPr)2 (1) \\
\hline Empirical formula & C47 H52 B N4 O2 V \\
\hline Formula weight & 766.67 \\
\hline Temperature & $123(2) \mathrm{K}$ \\
\hline Wavelength & $1.54178 \mathrm{~A}$ \\
\hline Crystal system, space group & Monoclinic, P2(1)/c \\
\hline Unit cell dimensions & $\mathrm{a}=16.072(1) \mathrm{A}$ alpha $=90 \mathrm{deg}$. \\
\hline & $\mathrm{b}=19.151(1) \mathrm{A} \quad$ beta $=91.727(5) \mathrm{deg}$. \\
\hline & $\mathrm{c}=27.288(2) \mathrm{A} \quad$ gamma $=90 \mathrm{deg}$. \\
\hline Volume & $8395.3(9) \mathrm{A}^{\wedge} 3$ \\
\hline Z, Calculated density & $8,1.213 \mathrm{Mg} / \mathrm{m}^{\wedge} 3$ \\
\hline Absorption coefficient & $2.297 \mathrm{~mm}^{\wedge}-1$ \\
\hline $\mathrm{F}(000)$ & 3248 \\
\hline Crystal color and shape & Orange flat column \\
\hline Crystal size & $0.40 \times 0.15 \times 0.08 \mathrm{~mm}$ \\
\hline Theta range for data collection & 2.750 to $65.975 \mathrm{deg}$. \\
\hline Limiting indices & $-18<=\mathrm{h}<=18,0<=\mathrm{k}<=22,0<=1<=32$ \\
\hline Reflections collected / unique & $53484 / 12756[\mathrm{R}($ int $)=0.0606]$ \\
\hline Completeness to theta $=65.975$ & $88.90 \%$ \\
\hline Absorption correction & Empirical \\
\hline Max. and min. transmission & 0.7527 and 0.3477 \\
\hline Refinement method & Full-matrix least-squares on $\mathrm{F}^{\wedge} 2$ \\
\hline Data / restraints / parameters & $11604 / 0 / 868$ \\
\hline Goodness-of-fit on $\mathrm{F}^{\wedge} 2$ & 1.125 \\
\hline Final $\mathrm{R}$ indices $[\mathrm{I}>4 \operatorname{sigma}(\mathrm{I})]$ & $\mathrm{R} 1=0.0692, w \mathrm{w} 2=0.1824$ \\
\hline $\mathrm{R}$ indices (all data) & $\mathrm{R} 1=0.0747, \mathrm{wR} 2=0.1860$ \\
\hline Largest diff. peak and hole & 0.795 and -0.619 e. $\mathrm{A}^{\wedge}-3$ \\
\hline
\end{tabular}




\section{S5. Ethylene Polymerization}

S5.1. General Procedure for Ethylene Polymerization. Polymerization was carried out in toluene in a $50 \mathrm{~mL}$ Parr reactor equipped with a magnetic stir bar. The Parr reactor was connected to a Schlenk line and degassed by three cycles of vacuum evacuation and backfill with $\mathrm{N}_{2}$. The reactor was heated to the set reaction temperature. After the temperature had stabilized, a solution of vanadium precatalyst $(0.0065 \mathrm{mmol})$ and toluene $(10 \mathrm{~mL})$ was injected through a ball valve with septum, followed by a solution of co-catalyst in toluene. After stirring vigorously for 5 minutes, the reaction was pressurized with ethylene. After a prescribed time, the reactor was carefully vented, and methanol $(10 \mathrm{~mL})$ was added to terminate the polymerization reaction. The resulting mixture was added to a 10:1 mixture of methanol and concentrated hydrochloric acid and stirred vigorously for 1 hour. The solid polyethylene was isolated by filtration, washed with methanol, and dried at $70{ }^{\circ} \mathrm{C}$ for 8 hours in vacuo.

S5.2. High-Temperature Gel Permeation Chromatography. HT-GPC was performed on a Tosoh EcoSEC HLC-8321 system with three TSKgel GMHHR-H(S) HT (7.8x300 $\mathrm{mm}$ ) columns with a HPLC grade $1,2,4$-trichlorobenzene flow of $1.0 \mathrm{~mL} / \mathrm{min}$ at $150^{\circ} \mathrm{C}$, or a Malvern Viscotek 350A HT-GPC system with three TSKgel GHMHRH(S)HT mixed bed columns with a HPLC grade 1,2,4-trichlorobenzene flow of $1.0 \mathrm{~mL} / \mathrm{min}$ at $160{ }^{\circ} \mathrm{C}$, if indicated. Molecular weights and molecular weight distributions were determined from signal response of the RI detector relative to a calibration curve made with polystyrene 
standards using $\mathrm{M} / \mathrm{H} \mathrm{K}=12.100 * 10^{-5} \mathrm{dL} / \mathrm{g}$ and alpha- 0.707 and a third order polynomial fit. RI -1.572 and $\mathrm{dn} / \mathrm{dc}=0.053$ or -0.097 for polystyrene or polyethylene, respectively. For reproducible results, all samples must be prepared freshly and run in batches of 4-5 samples maximum, as long periods of heating in excess of $140{ }^{\circ} \mathrm{C}$ in the instrument's autosampler resulted in sample degradation. HPLC grade 1,2,4-trichlorobenzene was purchased from VWR.

S5.3 Differential Scanning Calorimetry, General Procedure. Samples were analyzed on a Texas Instruments Q100 using a crimped standard sample pan. A double-scan method was used in order to eliminate inconsistencies due to variation in the thermal or mechanical history of individual samples. This method is summarized as follows: 1) Equilibrate at 0 ${ }^{\circ} \mathrm{C}$. 2) Heat at a rate of $10{ }^{\circ} \mathrm{C} /$ minute until $200{ }^{\circ} \mathrm{C}$. 3) Maintain $200{ }^{\circ} \mathrm{C}$ for two minutes. 4) Cool the sample at a rate of $10{ }^{\circ} \mathrm{C} /$ minute until $0{ }^{\circ} \mathrm{C}$. 5) Heat at a rate of $10{ }^{\circ} \mathrm{C} /$ minute until $200{ }^{\circ} \mathrm{C}$. 6) Maintain $200{ }^{\circ} \mathrm{C}$ for two minutes. 7) Cool the sample at a rate of $10{ }^{\circ} \mathrm{C} /$ minute until $0{ }^{\circ} \mathrm{C}$. Thermal parameters (heat of fusion and melting temperature maxima) were taken from the second heating cycle (step 5). Percent crystallinities were calculated based on $293 \mathrm{~J} / \mathrm{g}$ as the theoretical heat of fusion for a $100 \%$ crystalline sample $(\% \mathrm{C}=100 \%$ * $\Delta \mathrm{Hf} / 293 \mathrm{~J} / \mathrm{g}$ ) for polyethylene. (References: TA123 "Determination of Polymer Crystallinity by DSC," TA Instruments, New Castle, DE.; TN048, "Polymer Heats of Fusion," TA Instruments, New Castle, DE). 


\section{S5.4. Catalyst Development and Optimization Polymerization Results.}

Table S2.1. Optimization of ethylene polymerization with vanadium(V) tris(2pyridyl)borates.

\begin{tabular}{|c|c|c|c|c|c|c|c|}
\hline Entry $^{a}$ & Precatalyst & Cocatalyst & $\begin{array}{l}\text { Activity } \\
\mathrm{kg} / \mathrm{mol}^{*} \mathrm{~h}\end{array}$ & $T_{\mathrm{m}}\left({ }^{\circ} \mathrm{C}\right)^{\mathrm{d}}$ & $\% \mathrm{C}^{\mathrm{d}}$ & $M_{\mathrm{n}}^{\mathrm{e}}$ & $M_{\mathrm{m}} / M_{\mathrm{n}}^{\mathrm{e}}$ \\
\hline 1 & 1 & $\begin{array}{l}\text { MMAO- } \\
12^{\mathrm{b}}\end{array}$ & 85.8 & 123.9 & 78.1 & $\begin{array}{l}3464 \\
(2979)^{f}\end{array}$ & $\begin{array}{l}1.685 \\
(1.745)^{\mathrm{f}}\end{array}$ \\
\hline 2 & 2 & $\begin{array}{l}\text { MMAO- } \\
12^{\mathrm{b}}\end{array}$ & 24.2 & 129.1 & 25.4 & $62720^{f}$ & $6.285^{f}$ \\
\hline 3 & 3 & $\begin{array}{l}\text { MMAO- } \\
12^{\mathrm{b}}\end{array}$ & 80.2 & 128.6 & 67.8 & $8821^{\mathrm{f}}$ & $2.386^{f}$ \\
\hline 4 & 6 & $\begin{array}{l}\text { MMAO- } \\
12^{\mathrm{b}}\end{array}$ & 9.6 & 135.9 & 19.5 & $\underset{f}{385467}$ & $7.365^{f}$ \\
\hline 5 & 8 & $\begin{array}{l}\text { MMAO- } \\
12^{\mathrm{b}}\end{array}$ & 6.9 & 126.1 & 27.8 & $\begin{array}{l}343319 \\
\mathrm{f}\end{array}$ & $5.502^{f}$ \\
\hline 6 & $\mathrm{VOCl}_{3}$ & $\begin{array}{l}\text { MMAO- } \\
12^{\mathrm{b}}\end{array}$ & 4.1 & 133.6 & 55.2 & $\underset{f}{363414}$ & $2.877^{\mathrm{f}}$ \\
\hline 7 & 1 & $\begin{array}{l}\text { MMAO- } \\
12^{\mathrm{c}}\end{array}$ & 32.9 & 125.0 & 73.4 & 4221 & 1.715 \\
\hline 8 & 1 & $\mathrm{AlMe}_{3}{ }^{\mathrm{c}}$ & 0 & -- & -- & -- & -- \\
\hline 9 & 1 & $\mathrm{AlEt}_{2} \mathrm{Cl}^{\mathrm{c}}$ & 0 & -- & -- & -- & -- \\
\hline 10 & 1 & $\mathrm{AlEtCl}_{2}{ }^{\mathrm{c}}$ & 36.9 & 130.2 & 41.7 & $60247^{f}$ & $2.540^{\mathrm{f}}$ \\
\hline 11 & 1 & $\begin{array}{l}\text { D-MMAO- } \\
12^{\mathrm{c}}\end{array}$ & 22.9 & 128.4 & 36.5 & $60387^{f}$ & $3.429^{f}$ \\
\hline 12 & 5 & $\begin{array}{l}\text { MMAO- } \\
12^{\mathrm{b}}\end{array}$ & 1.6 & -- & -- & -- & -- \\
\hline
\end{tabular}

${ }^{\mathrm{a}} \mathrm{All}$ experiments performed at $75^{\circ} \mathrm{C}$ for $1 \mathrm{~h}$, with 10 bar ethylene, and $0.65 \mathrm{mM}$ concentration of catalyst. ${ }^{\mathrm{b}} \mathrm{At}$ a $400: 1 \mathrm{Al}: \mathrm{V}$ ratio. ${ }^{\mathrm{c}} \mathrm{At}$ a $200: 1 \mathrm{Al}: \mathrm{V}$ ratio. ${ }^{\text {dPeak }}$ melting temperature $\left(T_{\mathrm{m}}\right)$ and percent crystallinity $(\% \mathrm{C})$ obtained by differential scanning calorimetry. ${ }^{\mathrm{e}}$ Number-average molecular weight $\left(M_{\mathrm{n}}\right)$ and polydispersity index $\left(M_{\mathrm{m}} / M_{\mathrm{n}}\right)$ obtained by high-temperature gel permeation chromatography on the Tosoh instrument. ${ }^{\mathrm{f}}$ Obtained by analysis on the Malvern instrument.

Table 1, entry 1; Table S2.1, entry 1. According to the general procedure with $0.0065 \mathrm{mmol}$ 1 in $10 \mathrm{~mL}$ toluene, 400 eq. of MMAO and 10 bar ethylene at $75{ }^{\circ} \mathrm{C}$ for 1 hour. Yield: $0.5578 \mathrm{~g}, 20.7 \mathrm{mmol}$ ethylene. Turnover: $3178 \mathrm{~mol}$ ethylene/mol V*/hour, 85.8 
$\mathrm{kg} / \mathrm{mol} \mathrm{V} *$ hour. DSC: $T_{\mathrm{m}}=123.86^{\circ} \mathrm{C}, \Delta H_{\mathrm{f}}=228.73 \mathrm{~J} / \mathrm{g}$, crystallinity $=78.1 \%$. HT-GPC: $M_{\mathrm{n}}=3464, M_{\mathrm{m}}=5836, M_{\mathrm{m}} / M_{\mathrm{n}}=1.685$.

Table 1, entry 2; Table S2.1, entry 2. According to the general procedure with $0.0065 \mathrm{mmol}$ 2 in $10 \mathrm{~mL}$ toluene, 400 eq. of MMAO and 10 bar ethylene at $75{ }^{\circ} \mathrm{C}$ for 1 hour. Yield: $0.1574 \mathrm{~g}, 5.8 \mathrm{mmol}$ ethylene. Turnover: $897 \mathrm{~mol}$ ethylene/mol V*/hour, 24.0 $\mathrm{kg} / \mathrm{mol} \mathrm{V} *$ hour. DSC: $T_{\mathrm{m}}=129.05^{\circ} \mathrm{C}, \Delta H_{\mathrm{f}}=74.363 \mathrm{~J} / \mathrm{g}$, crystallinity $=25.4 \%$. HT-GPC: $M_{\mathrm{n}}=62720, M_{\mathrm{m}}=394168, M_{\mathrm{m}} / M_{\mathrm{n}}=6.285$.

Table 1, entry 3; Table S2.1, entry 3. According to the general procedure with $0.0065 \mathrm{mmol}$ 3 in $10 \mathrm{~mL}$ toluene, 400 eq. of MMAO and 10 bar ethylene at $75{ }^{\circ} \mathrm{C}$ for 1 hour. Yield: $0.5213 \mathrm{~g}, 19.3 \mathrm{mmol}$ ethylene. Turnover: $2970 \mathrm{~mol}$ ethylene/mol V*/hour, 80.2 $\mathrm{kg} / \mathrm{mol} \mathrm{V} *$ hour. DSC: $T_{\mathrm{m}}=128.62{ }^{\circ} \mathrm{C}, \Delta H_{\mathrm{f}}=198.76 \mathrm{~J} / \mathrm{g}$, crystallinity $=67.8 \%$. HT-GPC: $M_{\mathrm{n}}=8821, M_{\mathrm{m}}=21050, M_{\mathrm{m}} / M_{\mathrm{n}}=2.386$.

Table 1, entry 4; Table S2.1, entry 4. According to the general procedure with $0.0065 \mathrm{mmol}$ $\mathrm{VO}(\mathrm{OiPr})_{3}$ in $10 \mathrm{~mL}$ toluene, 400 eq. of MMAO and 10 bar ethylene at $75^{\circ} \mathrm{C}$ for 1 hour. Yield: $0.0627 \mathrm{~g}, 2.3 \mathrm{mmol}$ ethylene. Turnover: $357 \mathrm{~mol}$ ethylene/mol V*/hour, $9.6 \mathrm{~kg} / \mathrm{mol}$ $\mathrm{V} *$ hour. DSC: $T_{\mathrm{m}}=135.93{ }^{\circ} \mathrm{C}, \Delta H_{\mathrm{f}}=57.100 \mathrm{~J} / \mathrm{g}$, crystallinity $=19.5 \%$. HT-GPC: $M_{\mathrm{n}}=$ $385467, M_{\mathrm{m}}=2839000, M_{\mathrm{m}} / M_{\mathrm{n}}=7.365$.

Table 1, entry 5; Table S2.1, entry 5. According to the general procedure with $0.0065 \mathrm{mmol}$ $\mathrm{V}(\mathrm{NPh}) \mathrm{Cl}_{3}$ in $10 \mathrm{~mL}$ toluene, 400 eq. of MMAO and 10 bar ethylene at $75^{\circ} \mathrm{C}$ for 1 hour. Yield: $0.0452 \mathrm{~g}, 1.7 \mathrm{mmol}$ ethylene. Turnover: $257 \mathrm{~mol}$ ethylene/mol V*/hour, $6.9 \mathrm{~kg} / \mathrm{mol}$ 
$\mathrm{V} *$ hour. DSC: $T_{\mathrm{m}}=126.06{ }^{\circ} \mathrm{C}, \Delta H_{\mathrm{f}}=81.414 \mathrm{~J} / \mathrm{g}$, crystallinity $=27.8 \%$. HT-GPC: $M_{\mathrm{n}}=$ $343319, M_{\mathrm{m}}=1889000, M_{\mathrm{m}} / M_{\mathrm{n}}=5.502$.

Table 1, entry 6; Table S2.1, entry 6. According to the general procedure with $0.0065 \mathrm{mmol}$ $\mathrm{VOCl}_{3}$ in $10 \mathrm{~mL}$ toluene, 400 eq. of MMAO and 10 bar ethylene at $75^{\circ} \mathrm{C}$ for 1 hour. Yield: $0.0264 \mathrm{~g}, 0.97 \mathrm{mmol}$ ethylene. Turnover: $150 \mathrm{~mol}$ ethylene/mol V*/hour, 4.1 $\mathrm{kg} / \mathrm{mol} \mathrm{V} *$ hour. DSC: $T_{\mathrm{m}}=133.61{ }^{\circ} \mathrm{C}, \Delta H_{\mathrm{f}}=161.69 \mathrm{~J} / \mathrm{g}$, crystallinity $=55.2 \%$. HT-GPC: $M_{\mathrm{n}}=363413, M_{\mathrm{m}}=1046000, M_{\mathrm{m}} / M_{\mathrm{n}}=2.877$.

Table 1, entry 7; Table S2.1, entry 7. According to the general procedure with $0.0065 \mathrm{mmol}$ $1 \mathrm{in} 10 \mathrm{~mL}$ toluene, 200 eq. of MMAO and 10 bar ethylene at $75^{\circ} \mathrm{C}$ for $1 \mathrm{~h}$. Yield: $0.2140 \mathrm{~g}$, $7.9 \mathrm{mmol}$ ethylene. Turnover: $1219 \mathrm{~mol}$ ethylene $/ \mathrm{mol} \mathrm{V} * /$ hour, $32.9 \mathrm{~kg} / \mathrm{mol} \mathrm{V} *$ hour. DSC: $T_{\mathrm{m}}=125.02{ }^{\circ} \mathrm{C}, \Delta H_{\mathrm{f}}=215.02 \mathrm{~J} / \mathrm{g}$, crystallinity $=73.4 \%$. HT-GPC: $M_{\mathrm{n}}=4221, M_{\mathrm{m}}$ $=7240, M_{\mathrm{m}} / M_{\mathrm{n}}=1.715$.

Table 1, entry 8; Table S2.1, entry 8. According to the general procedure with $0.0065 \mathrm{mmol}$ $1 \mathrm{in} 10 \mathrm{~mL}$ toluene, 200 eq. of $\mathrm{AlMe}_{3}$ and 10 bar ethylene at $75^{\circ} \mathrm{C}$ for 1 hour. Yield: $0 \mathrm{~g}$. Table 1, entry 9; Table S2.1, entry 9. According to the general procedure with $0.0065 \mathrm{mmol}$ 1 in $10 \mathrm{~mL}$ toluene, 200 eq. of $\mathrm{AlEt}_{2} \mathrm{Cl}$ and 10 bar ethylene at $75^{\circ} \mathrm{C}$ for 1 hour. Yield: 0 g.

Table 1, entry 10; Table S2.1, entry 10. According to the general procedure with 0.0065 mmol 1 in $10 \mathrm{~mL}$ toluene, 200 eq. of $\mathrm{AlEtCl}_{2}$ and 10 bar ethylene at $75^{\circ} \mathrm{C}$ for 1 hour. Yield: $0.2400 \mathrm{~g}, 8.89 \mathrm{mmol}$ ethylene. Turnover: $1367 \mathrm{~mol}$ ethylene/mol V*/hour, 36.9 
$\mathrm{kg} / \mathrm{mol} \mathrm{V} *$ hour. DSC: $T_{\mathrm{m}}=130.22{ }^{\circ} \mathrm{C}, \Delta H_{\mathrm{f}}=122.18 \mathrm{~J} / \mathrm{g}$, crystallinity $=41.7 \%$. HT-GPC: $M_{\mathrm{n}}=60247, M_{\mathrm{m}}=152999, M_{\mathrm{m}} / M_{\mathrm{n}}=2.540$.

Table 1, entry 11; Table S2.1, entry 11. According to the general procedure with 0.0065 mmol 1 in $10 \mathrm{~mL}$ toluene, 200 eq. of D-MMAO-12 and 10 bar ethylene at $75^{\circ} \mathrm{C}$ for 1 hour. Yield: $0.1492 \mathrm{~g}, 5.5 \mathrm{mmol}$ ethylene. Turnover: $850 \mathrm{~mol}$ ethylene/mol V*/hour, 22.9 $\mathrm{kg} / \mathrm{mol} \mathrm{V} *$ hour. DSC: $T_{\mathrm{m}}=128.41{ }^{\circ} \mathrm{C}, \Delta H_{\mathrm{f}}=107.06 \mathrm{~J} / \mathrm{g}$, crystallinity $=36.5 \%$. HT-GPC: $M_{\mathrm{n}}=60387, M_{\mathrm{m}}=207094, M_{\mathrm{m}} / M_{\mathrm{n}}=3.429$.

Table S2.1, entry 12. According to the general procedure with $0.0065 \mathrm{mmol} 5 \mathrm{in} 10 \mathrm{~mL}$ toluene, 400 eq. of MMAO and 10 bar ethylene at $75^{\circ} \mathrm{C}$ for 1 hour. Yield: $0.0105 \mathrm{~g}, 1.61$ mmol ethylene. Turnover: 60 mol ethylene/mol V*/hour, $1.6 \mathrm{~kg} / \mathrm{mol} \mathrm{V} *$ hour.

\section{S5.5. Cocatalyst loading study.}

Table S2.2. Influence of Al: $\mathrm{V}$ ratio on catalysis by $1 / \mathrm{MMAO}-12$

\begin{tabular}{|l|l|l|l|l|l|l|}
\hline Entry $^{\mathrm{a}}$ & $\mathrm{Al}: \mathrm{V}$ & $\begin{array}{l}\text { Activity } \\
(\mathrm{kg} / \mathrm{mol} \mathrm{V} \text { (hr) }\end{array}$ & $T_{\mathrm{m}}\left({ }^{\circ} \mathrm{C}\right)^{\mathrm{b}}$ & $\% \mathrm{C}^{\mathrm{b}}$ & $M_{\mathrm{n}}{ }^{\mathrm{c}}$ & $M_{\mathrm{m}} / M_{\mathrm{n}}{ }^{\mathrm{c}}$ \\
\hline 1 & 25 & 13.5 & 134.93 & 36.2 & - & - \\
\hline 2 & 50 & 12.7 & 132.41 & 48.4 & $15 \times 10^{6}$ & $3.775^{\mathrm{d}}$ \\
\hline 3 & 100 & 11.6 & 128.19 & 75.7 & $8 \times 10^{5}$ & $1.006^{\mathrm{d}}$ \\
\hline 4 & 200 & 32.9 & 125.02 & 73.4 & 4221 & 1.715 \\
\hline 5 & 400 & 85.8 & 123.86 & 78.1 & 3464 & 1.685 \\
\hline 6 & 800 & 68.5 & 122.11 & 70.5 & 2944 & 1.461 \\
\hline 7 & 1600 & 211.7 & 122.03 & 53.1 & 3007 & 1.504 \\
\hline 8 & 3200 & 507.7 & 123.21 & 58.9 & 3159 & 1.551 \\
\hline 9 & 6400 & 201.4 & 124.64 & 48.2 & - & - \\
\hline
\end{tabular}

${ }^{a}$ All experiments performed at $75^{\circ} \mathrm{C}$ for $1 \mathrm{~h}$, with 10 bar ethylene, and $0.65 \mathrm{mM}$ concentration of $1 .{ }^{b}$ Peak melting temperature $\left(T_{\mathrm{m}}\right)$ and percent crystallinity $(\% \mathrm{C})$ obtained by differential scanning calorimetry. ${ }^{\mathrm{c}}$ Number-average molecular weight $\left(M_{\mathrm{n}}\right)$ and polydispersity index $\left(M_{\mathrm{m}} / M_{\mathrm{n}}\right)$ obtained by high-temperature gel permeation chromatography. ${ }^{\mathrm{d}}$ Multimodal distribution was observed. 
Table S2.2, entry 1. According to the general procedure with $0.0065 \mathrm{mmol} 1 \mathrm{in} 10 \mathrm{~mL}$ toluene, 25 eq. of MMAO and 10 bar ethylene at $75^{\circ} \mathrm{C}$ for 1 hour. Yield: $0.0876 \mathrm{~g}, 3.24$ mmol ethylene. Turnover: $499 \mathrm{~mol}$ ethylene $/ \mathrm{mol} \mathrm{V} * /$ hour, $13.5 \mathrm{~kg} / \mathrm{mol} \mathrm{V} *$ hour. DSC: $T_{\mathrm{m}}$ $=134.93{ }^{\circ} \mathrm{C}, \Delta H_{\mathrm{f}}=106.15 \mathrm{~J} / \mathrm{g}$, crystallinity $=36.2 \%$. HT-GPC was not performed due to low apparent solubility under the HT-GPC conditions.

Table S2.2, entry 2. According to the general procedure with $0.0065 \mathrm{mmol} 1 \mathrm{in} 10 \mathrm{ml}$ toluene, 50 eq. of MMAO and 10 bar ethylene at $75^{\circ} \mathrm{C}$ for 1 hour. Yield: $0.0824 \mathrm{~g}, 3.05$ mmol ethylene. Turnover: $469.5 \mathrm{~mol}$ ethylene $/ \mathrm{mol} \mathrm{V}^{*} /$ hour, $12.68 \mathrm{~kg} / \mathrm{mol} \mathrm{V} *$ hour. DSC: $T_{\mathrm{m}}=132.41^{\circ} \mathrm{C}, \Delta H_{\mathrm{f}}=141.78 \mathrm{~J} / \mathrm{g}$, crystallinity $=48.4 \%$. HT-GPC: $M_{\mathrm{n}}=15 \times 10^{6}, M_{\mathrm{m}}=$ $53 \times 10^{6}, M_{\mathrm{m}} / M_{\mathrm{n}}=3.775$.

Table S2.2, entry 3. According to the general procedure with $0.0065 \mathrm{mmol} 1 \mathrm{in} 10 \mathrm{~mL}$ toluene, 100 eq. of MMAO and 10 bar ethylene at $75^{\circ} \mathrm{C}$ for 1 hour. Yield: $0.0753 \mathrm{~g}, 2.79$ mmol ethylene. Turnover: 429 mol ethylene $/ \mathrm{mol} \mathrm{V} * /$ hour, $11.58 \mathrm{~kg} / \mathrm{mol} \mathrm{V} *$ hour. DSC: $T_{\mathrm{m}}=128.19^{\circ} \mathrm{C}, \Delta H_{\mathrm{f}}=221.83 \mathrm{~J} / \mathrm{g}$, crystallinity $=75.7 \%$. HT-GPC: $M_{\mathrm{n} 1}=8 \times 10^{5}, M_{\mathrm{m} 1}=$ $8 \times 10^{5}, M_{\mathrm{m} 1} / M_{\mathrm{n} 1}=1.006, M_{\mathrm{n} 2}=7008, M_{\mathrm{m} 2}=16026, M_{\mathrm{m} 2} / M_{\mathrm{n} 2}=2.286$

Table S2.2, entry 4. According to the general procedure with $0.0065 \mathrm{mmol} 1 \mathrm{in} 10 \mathrm{~mL}$ toluene, 200 eq. of MMAO and 10 bar ethylene at $75^{\circ} \mathrm{C}$ for 1 hour. Yield: $0.2140 \mathrm{~g}, 7.93$ mmol ethylene. Turnover: 1219 mol ethylene/mol V*/hour, $32.92 \mathrm{~kg} / \mathrm{mol} \mathrm{V} *$ hour. DSC: $T_{\mathrm{m}}=125.02^{\circ} \mathrm{C}, \Delta H_{\mathrm{f}}=215.02 \mathrm{~J} / \mathrm{g}$, crystallinity $=73.4 \%$. HT-GPC: $M_{\mathrm{n}}=4221, M_{\mathrm{m}}=7240$, $M_{\mathrm{m}} / M_{\mathrm{n}}=1.715$. 
Table S2.2, entry 5. According to the general procedure with $0.0065 \mathrm{mmol} \mathbf{1}$ in $10 \mathrm{~mL}$ toluene, 400 eq. of MMAO and 10 bar ethylene at $75^{\circ} \mathrm{C}$ for 1 hour. Yield: $0.5578 \mathrm{~g}, 20.7$ mmol ethylene. Turnover: $3178 \mathrm{~mol}$ ethylene $/ \mathrm{mol} \mathrm{V} * /$ hour, $85.8 \mathrm{~kg} / \mathrm{mol} \mathrm{V} *$ hour. DSC: $T_{\mathrm{m}}=123.86{ }^{\circ} \mathrm{C}, \Delta H_{\mathrm{f}}=228.73 \mathrm{~J} / \mathrm{g}$, crystallinity $=78.1 \%$. HT-GPC: $M_{\mathrm{n}}=3464, M_{\mathrm{m}}=5836$, $M_{\mathrm{m}} / M_{\mathrm{n}}=1.685$.

Table S2.2, entry 6. According to the general procedure with $0.0065 \mathrm{mmol} \mathbf{1}$ in $10 \mathrm{~mL}$ toluene, 800 eq. of MMAO and 10 bar ethylene at $75^{\circ} \mathrm{C}$ for 1 hour. Yield: $0.4453 \mathrm{~g}, 16.5$ mmol ethylene. Turnover: $2537 \mathrm{~mol}$ ethylene/mol V*/hour, $68.5 \mathrm{~kg} / \mathrm{mol} \mathrm{V} *$ hour. DSC: $T_{\mathrm{m}}=122.11^{\circ} \mathrm{C}, \Delta H_{\mathrm{f}}=206.55 \mathrm{~J} / \mathrm{g}$, crystallinity $=70.5 \%$. HT-GPC: $M_{\mathrm{n}}=2944, M_{\mathrm{m}}=4183$, $M_{\mathrm{m}} / M_{\mathrm{n}}=1.461$.

Table S2.2, entry 7. According to the general procedure with $0.0065 \mathrm{mmol} \mathbf{1}$ in $10 \mathrm{~mL}$ toluene, 1600 eq. of MMAO and 10 bar ethylene at $75^{\circ} \mathrm{C}$ for 1 hour. Yield: $1.3758 \mathrm{~g}$, $50.9 \mathrm{mmol}$ ethylene. Turnover: $7839 \mathrm{~mol}$ ethylene $/ \mathrm{mol} \mathrm{V} * /$ hour, $211.7 \mathrm{~kg} / \mathrm{mol} \mathrm{V} *$ hour. DSC: $T_{\mathrm{m}}=122.03{ }^{\circ} \mathrm{C}, \Delta H_{\mathrm{f}}=155.56 \mathrm{~J} / \mathrm{g}$, crystallinity $=53.1 \%$. HT-GPC: $M_{\mathrm{n}}=3007, M_{\mathrm{m}}$ $=4522, M_{\mathrm{m}} / M_{\mathrm{n}}=1.504$.

Table S2.2, entry 8. According to the general procedure with $0.0065 \mathrm{mmol} \mathbf{1}$ in $10 \mathrm{~mL}$ toluene, 3200 eq. of MMAO and 10 bar ethylene at $75^{\circ} \mathrm{C}$ for 1 hour. Yield: $3.3003 \mathrm{~g}$, $122.2 \mathrm{mmol}$ ethylene. Turnover: $18805 \mathrm{~mol}$ ethylene/mol V*/hour, $507.7 \mathrm{~kg} / \mathrm{mol} \mathrm{V} *$ hour. DSC: $T_{\mathrm{m}}=123.21{ }^{\circ} \mathrm{C}, \Delta H_{\mathrm{f}}=172.68 \mathrm{~J} / \mathrm{g}$, crystallinity $=58.9 \%$. HT-GPC: $M_{\mathrm{n}}=3159, M_{\mathrm{m}}$ $=4898, M_{\mathrm{m}} / M_{\mathrm{n}}=1.551$. 
Table S2.2, entry 9. According to the general procedure with $0.0032 \mathrm{mmol} \mathbf{1}$ in $5 \mathrm{~mL}$ toluene, 6400 eq. of MMAO and 10 bar ethylene at $75^{\circ} \mathrm{C}$ for 1 hour. Yield: $0.6444 \mathrm{~g}$, $23.9 \mathrm{mmol}$ ethylene. Turnover: $7458 \mathrm{~mol}$ ethylene/mol V*/hour, $201.4 \mathrm{~kg} / \mathrm{mol} \mathrm{V} *$ hour.

DSC: $T_{\mathrm{m}}=124.64{ }^{\circ} \mathrm{C}, \Delta H_{\mathrm{f}}=141.33 \mathrm{~J} / \mathrm{g}$, crystallinity $=48.2 \%$.

\section{S5.6. Temperature Study.}

Table S2.3. Influence of temperature on catalysis by $1 / \mathrm{MMAO}-12$

\begin{tabular}{|l|l|l|l|l|l|l|}
\hline Entry $^{\mathrm{a}}$ & $\begin{array}{l}\text { Reaction } \\
\text { Temperature }\left({ }^{\circ} \mathrm{C}\right)\end{array}$ & $\begin{array}{l}\text { Activity } \\
\left(\mathrm{kg} / \mathrm{mol} \mathrm{V}{ }^{*} \mathrm{hr}\right)\end{array}$ & $T_{\mathrm{M}}\left({ }^{\circ} \mathrm{C}\right)^{\mathrm{b}}$ & $\% \mathrm{C}^{\mathrm{b}}$ & $M_{\mathrm{N}}{ }^{\mathrm{c}}$ & $\mathrm{M}_{\mathrm{W}} / \mathrm{M}_{\mathrm{N}}{ }^{\mathrm{c}}$ \\
\hline 1 & 35 & 21.1 & 129.48 & 81.6 & $4.6 \times 10^{6}$ & $1.014^{\mathrm{d}}$ \\
\hline 2 & 50 & 20.6 & 129.90 & 81.4 & $2.8 \times 10^{6}$ & $1.364^{\mathrm{d}}$ \\
\hline 3 & 75 & 85.8 & 123.86 & 78.1 & 3464 & 1.685 \\
\hline 5 & 90 & 104.0 & 121.93 & 77.9 & 3221 & 1.472 \\
\hline 6 & 105 & 64.7 & 116.36 & $70.8^{\mathrm{d}}$ & 2692 & 1.314 \\
\hline
\end{tabular}

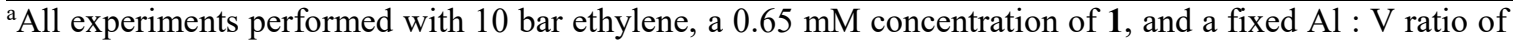

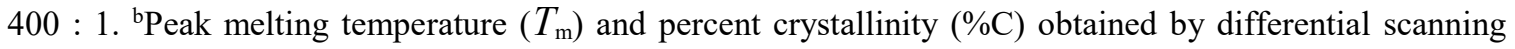
calorimetry. ${ }^{c}$ Number-average molecular weight $\left(M_{\mathrm{n}}\right)$ and polydispersity index $\left(M_{\mathrm{m}} / M_{\mathrm{n}}\right)$ obtained by hightemperature gel permeation chromatography. ${ }^{\mathrm{d}}$ Multimodal distribution was observed.

Table S2.3, entry 1. According to the general procedure with $0.0065 \mathrm{mmol} \mathbf{1}$ in $10 \mathrm{~mL}$ toluene, 400 eq. of MMAO and 10 bar ethylene at $50{ }^{\circ} \mathrm{C}$ for 1 hour. Yield: $0.1374 \mathrm{~g}, 5.1$ mmol ethylene. Turnover: $783 \mathrm{~mol}$ ethylene $/ \mathrm{mol} \mathrm{V} * /$ hour, $21.1 \mathrm{~kg} / \mathrm{mol} \mathrm{V} *$ hour. DSC: $T_{\mathrm{m}}$ $=129.48{ }^{\circ} \mathrm{C}, \Delta H_{\mathrm{f}}=239.21 \mathrm{~J} / \mathrm{g}$, crystallinity $=81.6 \%$. HT-GPC: $M_{\mathrm{n} 1}=4.6 \times 10^{6}, M_{\mathrm{m} 1}=$ $4.7 \times 10^{6}, M_{\mathrm{m} 2} / M_{\mathrm{n} 2}=1.014, M_{\mathrm{n} 2}=1713, M_{\mathrm{m} 2}=1947, M_{\mathrm{m} 2} / M_{\mathrm{n} 2}=1.137$

Table S2.3, entry 2. According to the general procedure with $0.0065 \mathrm{mmol} \mathbf{1}$ in $10 \mathrm{~mL}$ toluene, 400 eq. of MMAO and 10 bar ethylene at $50{ }^{\circ} \mathrm{C}$ for 1 hour. Yield: $0.1338 \mathrm{~g}, 4.9$ mmol ethylene. Turnover: $762 \mathrm{~mol}$ ethylene $/ \mathrm{mol} \mathrm{V} * /$ hour, $20.6 \mathrm{~kg} / \mathrm{mol} \mathrm{V} *$ hour. DSC: $T_{\mathrm{m}}$ 
$=129.90{ }^{\circ} \mathrm{C}, \Delta H_{\mathrm{f}}=238.62 \mathrm{~J} / \mathrm{g}$, crystallinity $=81.4 \%$. HT-GPC: $M_{\mathrm{n} 1}=2.8 \times 10^{6}, M_{\mathrm{m} 1}=$ $3.8 \times 10^{6}, M_{\mathrm{m} 1} / M_{\mathrm{n} 1}=1.364, M_{\mathrm{n} 2}=9452, M_{\mathrm{m} 2}=2.3 \times 10^{4}, M_{\mathrm{m} 2} / M_{\mathrm{n} 2}=2.420$

Table S2.3, entry 3. According to the general procedure with $0.0065 \mathrm{mmol} 1 \mathrm{in} 10 \mathrm{~mL}$ toluene, 400 eq. of MMAO and 10 bar ethylene at $75^{\circ} \mathrm{C}$ for 1 hour. Yield: $0.5578 \mathrm{~g}, 20.7$ mmol ethylene. Turnover: 3178 mol ethylene $/ \mathrm{mol} \mathrm{V}^{*} /$ hour, $85.8 \mathrm{~kg} / \mathrm{mol} \mathrm{V} *$ hour. DSC: $T_{\mathrm{m}}=123.86^{\circ} \mathrm{C}, \Delta H_{\mathrm{f}}=228.73 \mathrm{~J} / \mathrm{g}$, crystallinity $=78.1 \%$. HT-GPC: $M_{\mathrm{n}}=3464, M_{\mathrm{m}}=5836$, $M_{\mathrm{m}} / M_{\mathrm{n}}=1.685$.

Table S2.3, entry 4. According to the general procedure with $0.0065 \mathrm{mmol} 1 \mathrm{in} 10 \mathrm{~mL}$ toluene, 400 eq. of MMAO and 10 bar ethylene at $90{ }^{\circ} \mathrm{C}$ for 1 hour. Yield: $0.6784 \mathrm{~g}, 25.1$ mmol. Turnover: $3865 \mathrm{~mol}$ ethylene $/ \mathrm{mol} \mathrm{V} * /$ hour, $104.0 \mathrm{~kg} / \mathrm{mol} \mathrm{V} *$ hour. DSC: $T_{\mathrm{m}}=$ $121.93^{\circ} \mathrm{C}, \Delta H \mathrm{f}=228.20 \mathrm{~J} / \mathrm{g}$, crystallinity $=77.9 \%$. HT-GPC: $M_{\mathrm{n}}=3221, M_{\mathrm{m}}=4740$, $M_{\mathrm{m}} / M_{\mathrm{n}}=1.472$.

Table S2.3, entry 5. According to the general procedure with $0.0065 \mathrm{mmol} 1 \mathrm{in} 10 \mathrm{~mL}$ toluene, 400 eq. of MMAO and 10 bar ethylene at $105^{\circ} \mathrm{C}$ for 1 hour. Yield: $0.4207 \mathrm{~g}, 15.6$ mmol. Turnover: $2397 \mathrm{~mol}$ ethylene $/ \mathrm{mol} \mathrm{V} * /$ hour, $64.7 \mathrm{~kg} / \mathrm{mol} \mathrm{V} *$ hour. DSC: $T_{\mathrm{m}}=$ $116.36^{\circ} \mathrm{C}, \Delta H_{\mathrm{f}}=189.43 \mathrm{~J} / \mathrm{g}$, crystallinity $=70.8 \%$. HT-GPC: $M_{\mathrm{n}}=2692, M_{\mathrm{m}}=3487$, $M_{\mathrm{m}} / M_{\mathrm{n}}=1.296$.

Table S2.3, entry 6. According to the general procedure with $0.0065 \mathrm{mmol} 1 \mathrm{in} 10 \mathrm{~mL}$ toluene, 400 eq. of MMAO and 10 bar ethylene at $120^{\circ} \mathrm{C}$ for 1 hour. Yield: $0.0764 \mathrm{~g}, 2.8$ mmol. Turnover: $435 \mathrm{~mol}$ ethylene $/ \mathrm{mol} \mathrm{V} * /$ hour, $11.7 \mathrm{~kg} / \mathrm{mol} \mathrm{V} *$ hour. DSC: $T_{\mathrm{m}}=$ 
$119.45^{\circ} \mathrm{C}, \Delta H_{\mathrm{f}}=249.50 \mathrm{~J} / \mathrm{g}$, crystallinity $=85.0 \%$. HT-GPC: $M_{\mathrm{n}}=2228, M_{\mathrm{w}}=2679$, $\mathrm{M}_{\mathrm{W}} / \mathrm{M}_{\mathrm{N}}=1.202$.

\section{S5.7. Pressure study.}

Table S2.4. Influence of ethylene pressure on catalysis by $1 / \mathrm{MMAO}-12$

\begin{tabular}{|l|l|l|l|l|l|l|}
\hline Entry $^{\mathrm{a}}$ & $\begin{array}{l}\text { Ethylene } \\
\text { Pressure (bar) }\end{array}$ & $\begin{array}{l}\text { Activity } \\
(\mathrm{kg} / \mathrm{mol} \mathrm{V} \text { (hr) }\end{array}$ & $T_{\mathrm{m}}\left({ }^{\circ} \mathrm{C}\right)^{\mathrm{b}}$ & $\mathrm{\% C}^{\mathrm{b}}$ & $M_{\mathrm{n}}{ }^{\mathrm{c}}$ & $M_{\mathrm{m}} / M_{\mathrm{n}}{ }^{\mathrm{c}}$ \\
\hline 1 & 1 & 0.6 & - & - & - & - \\
\hline 2 & 6 & 43.6 & 125.01 & 75.9 & 3692 & 1.591 \\
\hline 3 & 10 & 85.8 & 123.86 & 78.1 & 3464 & 1.685 \\
\hline 4 & 20 & 116.0 & 123.4 & 69.5 & 3566 & 1.707 \\
\hline 5 & 40 & 121.4 & 124.2 & 66.8 & 3387 & $1.673^{\mathrm{d}}$ \\
\hline
\end{tabular}

${ }^{a}$ All experiments performed at $75^{\circ} \mathrm{C}$, a $0.65 \mathrm{mM}$ concentration of 1 , and a fixed $\mathrm{Al}: \mathrm{V}$ ratio of $400: 1$. ${ }^{\mathrm{b}} \mathrm{Peak}$ melting temperature $\left(T_{\mathrm{m}}\right)$ and percent crystallinity $(\% \mathrm{C})$ obtained by differential scanning calorimetry. 'Number-average molecular weight $\left(M_{\mathrm{n}}\right)$ and polydispersity index $\left(M_{\mathrm{m}} / M_{\mathrm{n}}\right)$ obtained by high-temperature gel permeation chromatography. ${ }^{\mathrm{d}}$ Multimodal distribution was observed.

Table S2.4, entry 1. According to the general procedure with $0.0065 \mathrm{mmol} 1 \mathrm{in} 10 \mathrm{~mL}$ toluene, 400 eq. of MMAO and 1 bar ethylene at $75{ }^{\circ} \mathrm{C}$ for 1 hour. Yield: $0.0039 \mathrm{~g}$, 0.14mmol. Turnover: $22 \mathrm{~mol}$ ethylene $/ \mathrm{mol} \mathrm{V*/hour,} 0.6 \mathrm{~kg} / \mathrm{mol} \mathrm{V} *$ hour.

Table S2.4, entry 2. According to the general procedure with $0.0065 \mathrm{mmol} 1 \mathrm{in} 10 \mathrm{~mL}$ toluene, 400 eq. of MMAO and 6 bar ethylene at $75{ }^{\circ} \mathrm{C}$ for 1 hour. Yield: $0.2837 \mathrm{~g}, 10.5$ mmol ethylene. Turnover: 1616 mol ethylene $/ \mathrm{mol} \mathrm{V} * /$ hour, $43.6 \mathrm{~kg} / \mathrm{mol} \mathrm{V} *$ hour. DSC: $T_{\mathrm{m}}=125.01^{\circ} \mathrm{C}, \Delta H_{\mathrm{f}}=222.36 \mathrm{~J} / \mathrm{g}$, crystallinity $=75.9 \%$. HT-GPC: $M_{\mathrm{n}}=3692, M_{\mathrm{m}}=5872$, $M_{\mathrm{m}} / M_{\mathrm{n}}=1.591$.

Table S2.4, entry 3. According to the general procedure with $0.0065 \mathrm{mmol} 1 \mathrm{in} 10 \mathrm{~mL}$ toluene, 400 eq. of MMAO and 10 bar ethylene at $75^{\circ} \mathrm{C}$ for 1 hour. Yield: $0.5578 \mathrm{~g}, 20.7$ 
mmol ethylene. Turnover: $3178 \mathrm{~mol}$ ethylene/mol V*/hour, $85.8 \mathrm{~kg} / \mathrm{mol} \mathrm{V} *$ hour. DSC: $T_{\mathrm{m}}=123.86^{\circ} \mathrm{C}, \Delta H_{\mathrm{f}}=228.73 \mathrm{~J} / \mathrm{g}$, crystallinity $=78.1 \%$. HT-GPC: $M_{\mathrm{n}}=3464, M_{\mathrm{m}}=5836$, $M_{\mathrm{m}} / M_{\mathrm{n}}=1.685$.

Table S2.4, entry 4. According to the general procedure with $0.0065 \mathrm{mmol} 1 \mathrm{in} 10 \mathrm{~mL}$ toluene, 400 eq. of MMAO and 20 bar ethylene at $75^{\circ} \mathrm{C}$ for 1 hour. Yield: $0.7568 \mathrm{~g}, 28.0$ mmol ethylene. Turnover: $4312 \mathrm{~mol}$ ethylene $/ \mathrm{mol} \mathrm{V}^{*} /$ hour, $116.0 \mathrm{~kg} / \mathrm{mol} \mathrm{V} *$ hour. DSC: $T_{\mathrm{m}}=123.4{ }^{\circ} \mathrm{C}, \Delta H_{\mathrm{f}}=203.61 \mathrm{~J} / \mathrm{g}$, crystallinity $=69.5 \%$. HT-GPC: $M_{\mathrm{n}}=3566, M_{\mathrm{m}}=6089$, $M_{\mathrm{m}} / M_{\mathrm{n}}=1.707$.

Table S2.4, entry 4. According to the general procedure with $0.0065 \mathrm{mmol} 1 \mathrm{in} 10 \mathrm{~mL}$ toluene, 400 eq. of MMAO and 40 bar ethylene at $75^{\circ} \mathrm{C}$ for 1 hour. Yield: $0.7891 \mathrm{~g}, 29.2$ mmol ethylene. Turnover: 4496 mol ethylene/mol V*/hour, $121.4 \mathrm{~kg} / \mathrm{mol} \mathrm{V} *$ hour. DSC: $T_{\mathrm{m}}=124.2{ }^{\circ} \mathrm{C}, \Delta H_{\mathrm{f}}=195.82 \mathrm{~J} / \mathrm{g}$, crystallinity $=66.8 \%$. HT-GPC: $M_{\mathrm{n}}=3387, M_{\mathrm{m}}=5666$, $M_{\mathrm{m}} / M_{\mathrm{n}}=1.673$.

\section{S5.7. Time Study.}

Table S2.5. Time points taken at $75^{\circ} \mathrm{C}$ with by $1 / \mathrm{MMAO}-12$

\begin{tabular}{|l|l|l|l|l|}
\hline Entry $^{\mathrm{a}}$ & $\begin{array}{l}\text { Reaction Time } \\
(\mathrm{minutes})\end{array}$ & yield $(\mathrm{g})$ & $\begin{array}{l}\text { Activity } \\
(\mathrm{kg} / \mathrm{mol} \mathrm{V} \text { (hr) }\end{array}$ & $\begin{array}{l}\text { TON } \\
(\mathrm{mol} \text { ethylene/mol V/ hr) }\end{array}$ \\
\hline 1 & 15 & 0.0594 & 36.5 & 1354 \\
\hline 2 & 30 & 0.2113 & 65.0 & 2407 \\
\hline 3 & 45 & 0.3669 & 75.3 & 2787 \\
\hline 4 & 60 & 0.5578 & 85.8 & 3178 \\
\hline 5 & 90 & 0.6994 & 71.7 & 2657 \\
\hline 6 & 120 & 0.7840 & 60.3 & 2234 \\
\hline 7 & 240 & 0.7602 & 29.2 & 1083 \\
\hline
\end{tabular}


${ }^{a}$ All experiments performed at $75{ }^{\circ} \mathrm{C}$ with 10 bar ethylene, a $0.65 \mathrm{mM}$ concentration of 1 , and a fixed $\mathrm{Al}: \mathrm{V}$ ratio of $400: 1$.

Table S2.5, entry 1. According to the general procedure with $0.0065 \mathrm{mmol} \mathbf{1}$ in $10 \mathrm{~mL}$ toluene, 400 eq. of MMAO and 10 bar ethylene at $75^{\circ} \mathrm{C}$ for 0.25 hours. Yield: $0.0594 \mathrm{~g}$, $2.2 \mathrm{mmol}$ ethylene. Turnover: $1354 \mathrm{~mol}$ ethylene $/ \mathrm{mol} \mathrm{V} * /$ hour, $36.5 \mathrm{~kg} / \mathrm{mol} \mathrm{V} *$ hour.

Table S2.5, entry 2. According to the general procedure with $0.0065 \mathrm{mmol} \mathbf{1}$ in $10 \mathrm{~mL}$ toluene, 400 eq. of MMAO and 10 bar ethylene at $75^{\circ} \mathrm{C}$ for 0.5 hours. Yield: $0.2113 \mathrm{~g}$, $7.8 \mathrm{mmol}$ ethylene. Turnover: $2407 \mathrm{~mol}$ ethylene $/ \mathrm{mol} \mathrm{V} * /$ hour, $65.0 \mathrm{~kg} / \mathrm{mol} \mathrm{V} *$ hour.

Table S2.5, entry 3. According to the general procedure with $0.0065 \mathrm{mmol} \mathbf{1}$ in $10 \mathrm{~mL}$ toluene, 400 eq. of MMAO and 10 bar ethylene at $75^{\circ} \mathrm{C}$ for 0.75 hours. Yield: $0.3669 \mathrm{~g}$, $13.6 \mathrm{mmol}$ ethylene. Turnover: $2787 \mathrm{~mol}$ ethylene/mol V*/hour, $75.3 \mathrm{~kg} / \mathrm{mol} \mathrm{V} *$ hour.

Table S2.5, entry 4. According to the general procedure with $0.0065 \mathrm{mmol} \mathbf{1}$ in $10 \mathrm{~mL}$ toluene, 400 eq. of MMAO and 10 bar ethylene at $75^{\circ} \mathrm{C}$ for 1 hour. Yield: $0.5578 \mathrm{~g}, 20.7$ mmol ethylene. Turnover: $3178 \mathrm{~mol}$ ethylene/mol V*/hour, $85.8 \mathrm{~kg} / \mathrm{mol} \mathrm{V} *$ hour.

Table S2.5, entry 5. According to the general procedure with $0.0065 \mathrm{mmol} \mathbf{1}$ in $10 \mathrm{~mL}$ toluene, 400 eq. of MMAO and 10 bar ethylene at $75^{\circ} \mathrm{C}$ for 1.5 hours. Yield: $0.6994 \mathrm{~g}$, $25.9 \mathrm{mmol}$ ethylene. Turnover: $2657 \mathrm{~mol}$ ethylene/mol V*/hour, $71.7 \mathrm{~kg} / \mathrm{mol} \mathrm{V} *$ hour.

Table S2.5, entry 6. According to the general procedure with $0.0065 \mathrm{mmol} 1$ in $10 \mathrm{~mL}$ toluene, 400 eq. of MMAO and 10 bar ethylene at $75^{\circ} \mathrm{C}$ for 2 hours. Yield: $\quad 0.7840 \mathrm{~g}, 29.0$ mmol ethylene. Turnover: $2234 \mathrm{~mol}$ ethylene/mol V*/hour, $60.3 \mathrm{~kg} / \mathrm{mol} \mathrm{V} *$ hour. 
Table S2.5, entry 7. According to the general procedure with $0.0065 \mathrm{mmol} 1 \mathrm{in} 10 \mathrm{~mL}$ toluene, 400 eq. of MMAO and 10 bar ethylene at $75^{\circ} \mathrm{C}$ for 4 hours. Yield: $0.7602 \mathrm{~g}, 28.2$ mmol ethylene. Turnover: $1083 \mathrm{~mol}$ ethylene $/ \mathrm{mol} \mathrm{V}$ */hour, $29.2 \mathrm{~kg} / \mathrm{mol} \mathrm{V} *$ hour.

Table S2.6. Time points taken at $105^{\circ} \mathrm{C}$ with by $\mathbf{1} / \mathrm{MMAO}-12$

\begin{tabular}{|l|l|l|l|l|}
\hline Entry $^{\mathrm{a}}$ & $\begin{array}{l}\text { Reaction Time } \\
(\text { minutes })\end{array}$ & $\begin{array}{l}\text { yield } \\
(\mathrm{g})\end{array}$ & $\begin{array}{l}\text { Activity } \\
(\mathrm{kg} / \mathrm{mol} \mathrm{V} \text { (hr) }\end{array}$ & $\begin{array}{l}\text { TON } \\
(\mathrm{mol} \text { ethylene/mol }[\mathrm{V}] / \mathrm{hr})\end{array}$ \\
\hline 1 & 15 & 0.0222 & 13.7 & 508 \\
\hline 2 & 30 & 0.1722 & 53.0 & 1963 \\
\hline 3 & 45 & 0.3081 & 63.2 & 2341 \\
\hline 4 & 60 & 0.4207 & 64.7 & 2397 \\
\hline 5 & 90 & 0.4258 & 43.7 & 1617 \\
\hline 6 & 120 & 0.4210 & 32.4 & 1199 \\
\hline 7 & 240 & 0.4243 & 16.3 & 604 \\
\hline
\end{tabular}

${ }^{\mathrm{a}} \mathrm{All}$ experiments performed at $105^{\circ} \mathrm{C}$ with 10 bar ethylene, a $0.65 \mathrm{mM}$ concentration of $\mathbf{1}$, and a fixed $\mathrm{Al}$ : V ratio of $400: 1$.

Table S2.6, entry 1. According to the general procedure with $0.0065 \mathrm{mmol} 1 \mathrm{in} 10 \mathrm{~mL}$ toluene, 400 eq. of MMAO and 10 bar ethylene at $105^{\circ} \mathrm{C}$ for 0.25 hours. Yield: 0.0222 g, $0.8 \mathrm{mmol}$ ethylene. Turnover: $508 \mathrm{~mol}$ ethylene $/ \mathrm{mol} \mathrm{V}$ */hour, $13.7 \mathrm{~kg} / \mathrm{mol} \mathrm{V} *$ hour.

Table S2.6, entry 2. According to the general procedure with $0.0065 \mathrm{mmol} 1 \mathrm{in} 10 \mathrm{~mL}$ toluene, 400 eq. of MMAO and 10 bar ethylene at $105^{\circ} \mathrm{C}$ for 0.5 hours. Yield: $0.1722 \mathrm{~g}$, $6.4 \mathrm{mmol}$ ethylene. Turnover: $1963 \mathrm{~mol}$ ethylene $/ \mathrm{mol} \mathrm{V}$ */hour, $53.0 \mathrm{~kg} / \mathrm{mol} \mathrm{V} *$ hour. Table S2.6, entry 3. According to the general procedure with $0.0065 \mathrm{mmol} 1 \mathrm{in} 10 \mathrm{~mL}$ toluene, 400 eq. of MMAO and 10 bar ethylene at $105^{\circ} \mathrm{C}$ for 0.75 hours. Yield: 0.3081 g, 11.4 mmol ethylene. Turnover: $2341 \mathrm{~mol}$ ethylene/mol V*/hour, $63.2 \mathrm{~kg} / \mathrm{mol} \mathrm{V} *$ hour. 
Table S2.6, entry 4. According to the general procedure with $0.0065 \mathrm{mmol} 1 \mathrm{in} 10 \mathrm{~mL}$ toluene, 400 eq. of MMAO and 10 bar ethylene at $105^{\circ} \mathrm{C}$ for 1 hour. Yield: $0.4207 \mathrm{~g}$, $15.6 \mathrm{mmol}$ ethylene. Turnover: $2397 \mathrm{~mol}$ ethylene $/ \mathrm{mol} \mathrm{V}$ */hour, $64.7 \mathrm{~kg} / \mathrm{mol} \mathrm{V} *$ hour. Table S2.6, entry 5. According to the general procedure with $0.0065 \mathrm{mmol} 1 \mathrm{in} 10 \mathrm{~mL}$ toluene, 400 eq. of MMAO and 10 bar ethylene at $105^{\circ} \mathrm{C}$ for 1.5 hours. Yield: $0.4258 \mathrm{~g}$, $15.8 \mathrm{mmol}$ ethylene. Turnover: $1617 \mathrm{~mol}$ ethylene $/ \mathrm{mol} \mathrm{V}$ */hour, $43.7 \mathrm{~kg} / \mathrm{mol} \mathrm{V} *$ hour. Table S2.6, entry 6. According to the general procedure with $0.0065 \mathrm{mmol} 1 \mathrm{in} 10 \mathrm{~mL}$ toluene, 400 eq. of MMAO and 10 bar ethylene at $105^{\circ} \mathrm{C}$ for 2 hours. Yield: $0.4210 \mathrm{~g}$, $15.6 \mathrm{mmol}$ ethylene. Turnover: $1199 \mathrm{~mol}$ ethylene $/ \mathrm{mol} \mathrm{V}$ */hour, $32.4 \mathrm{~kg} / \mathrm{mol} \mathrm{V} *$ hour. Table S2.6, entry 7. According to the general procedure with $0.0065 \mathrm{mmol} 1 \mathrm{in} 10 \mathrm{~mL}$ toluene, 400 eq. of MMAO and 10 bar ethylene at $105^{\circ} \mathrm{C}$ for 4 hours. Yield: $0.4243 \mathrm{~g}$, $15.7 \mathrm{mmol}$ ethylene. Turnover: $604 \mathrm{~mol}$ ethylene $/ \mathrm{mol} \mathrm{V} * /$ hour, $16.3 \mathrm{~kg} / \mathrm{mol} \mathrm{V} *$ hour. 


\section{S6. Gel Permeation Chromatography Data for Polymer Products}

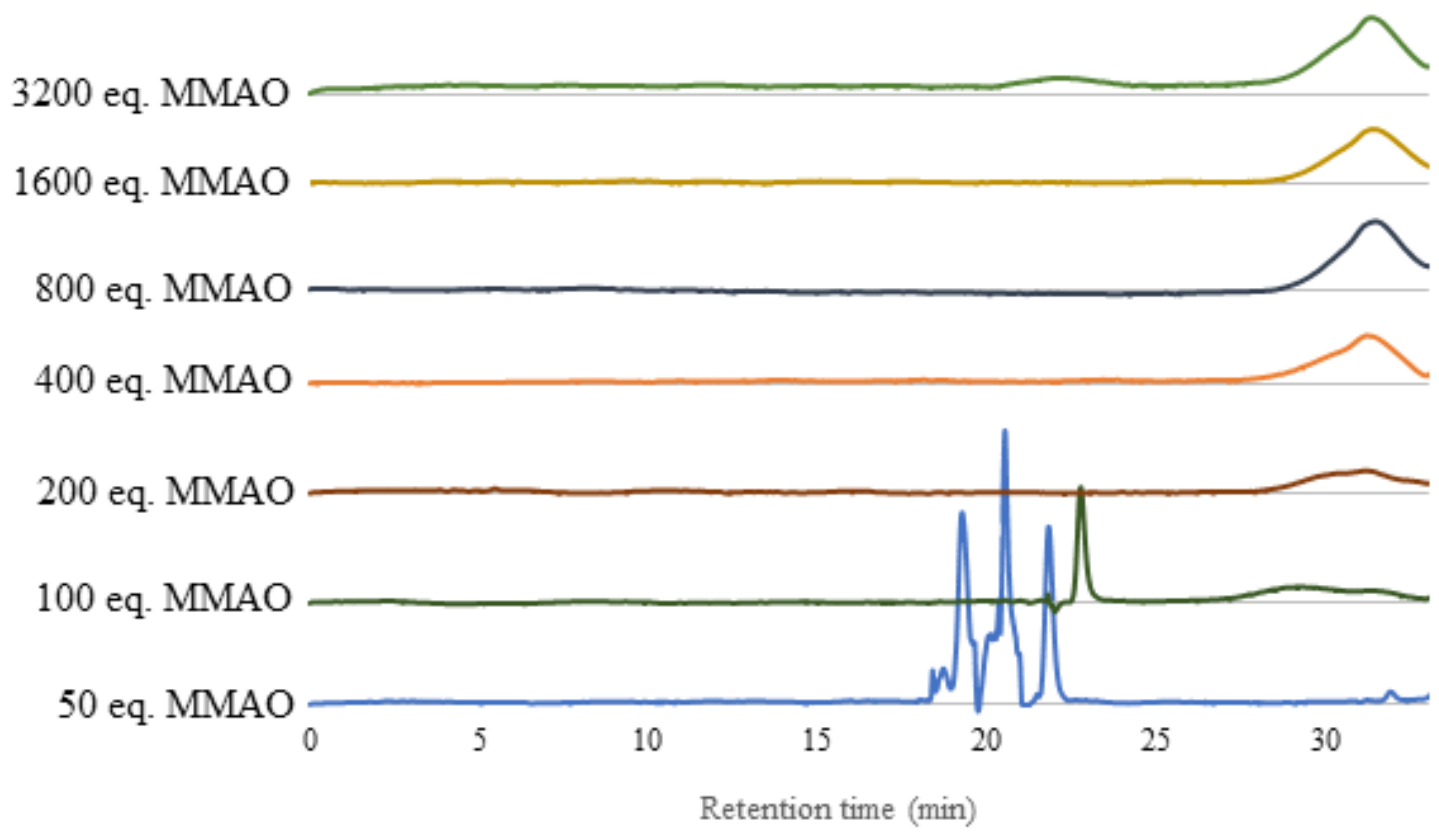

Figure S3.1. Gel permeation chromatography chromatogram for Table S5.2

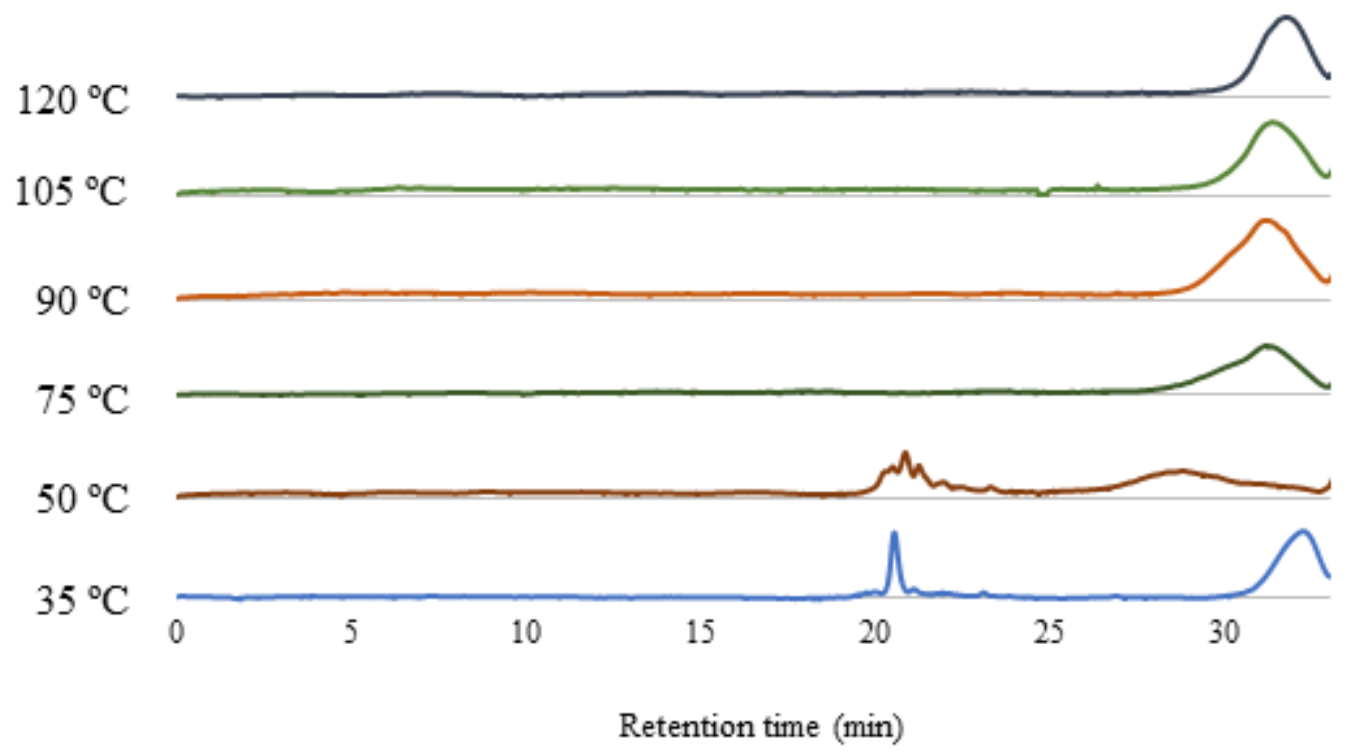

Figure S3.2. Gel permeation chromatography chromatogram for Table S5.3 


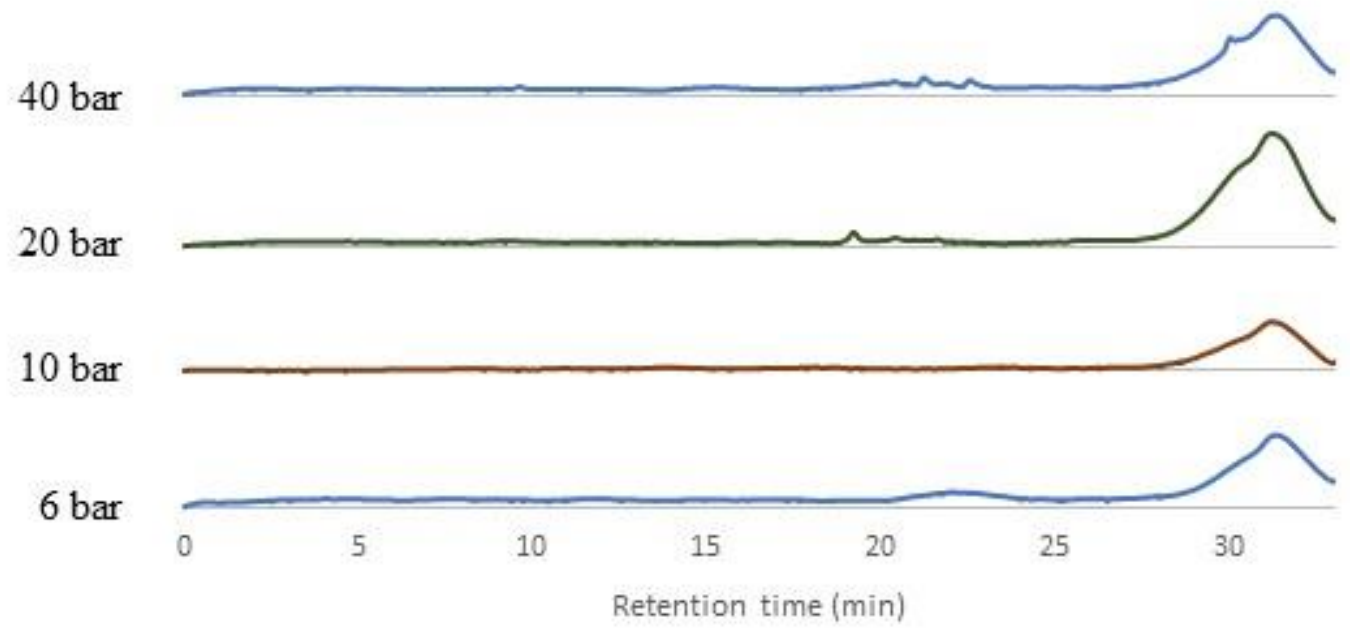

Figure S3.3. Gel permeation chromatography chromatogram for Table S5.4 


\section{S7. Calorimetry Data for Polymer Products}

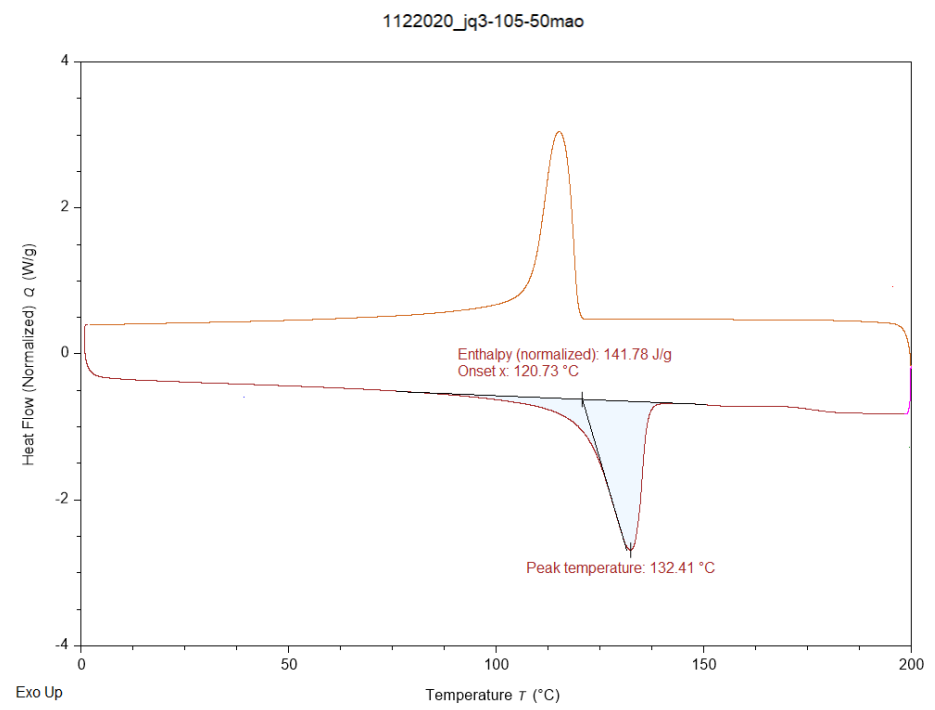

Figure S4.1. Differential scanning calorimetry thermogram for Table S5.2, entry 2.

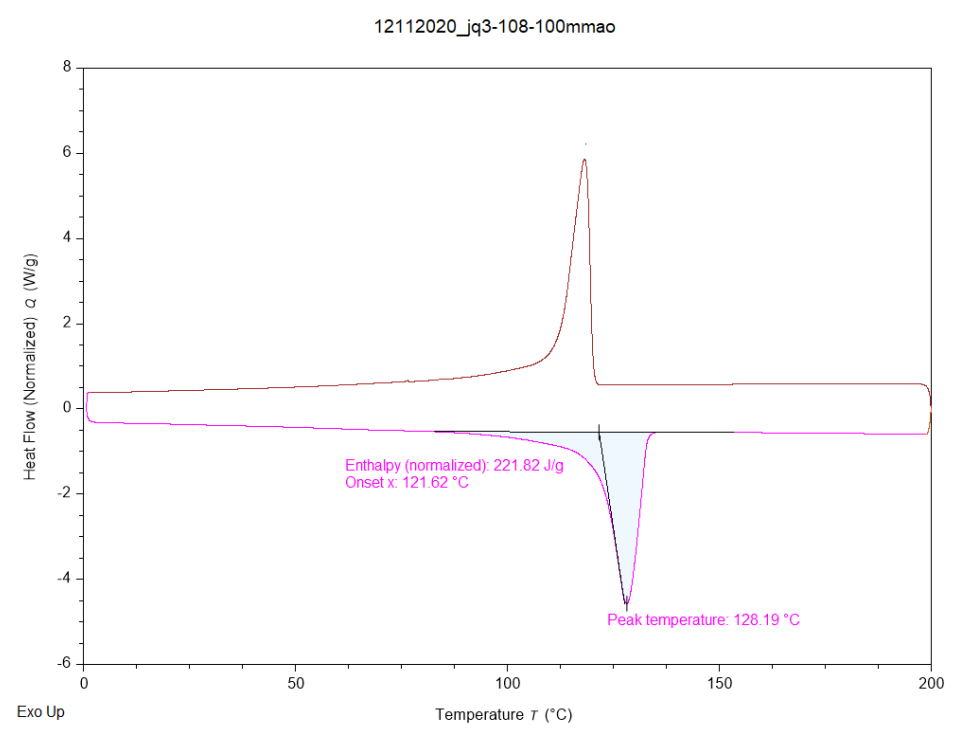

Figure S4.2. Differential scanning calorimetry thermogram for Table S5.2, entry 3. 


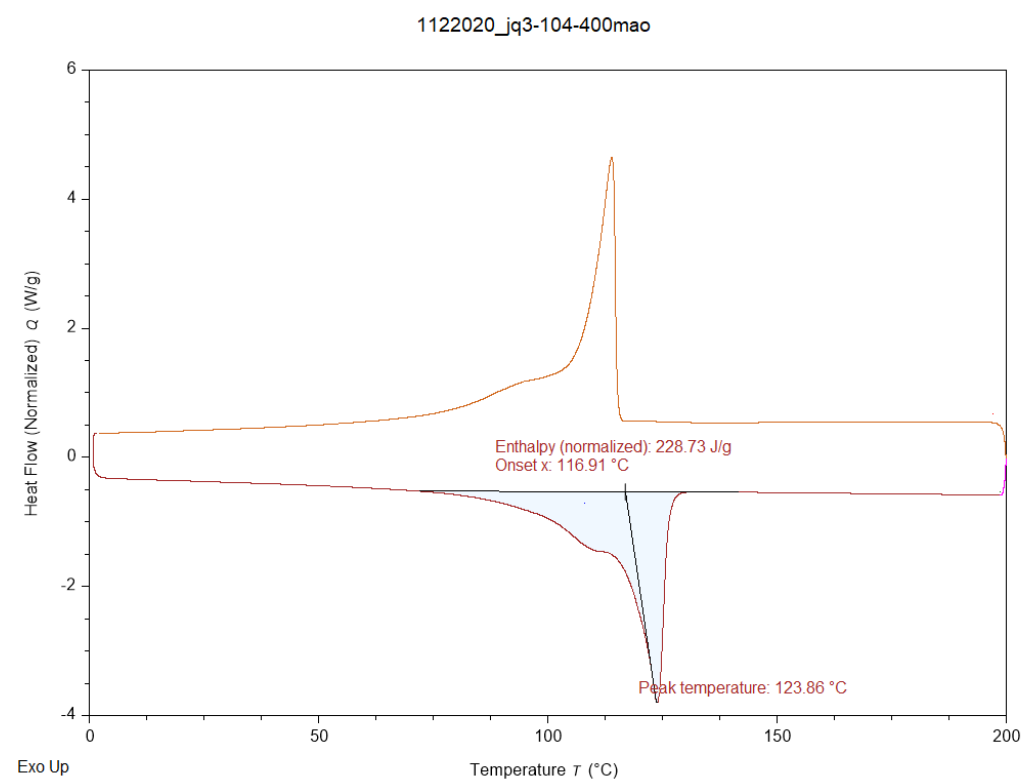

Figure S4.3. Differential scanning calorimetry thermogram for Table S5.1, entry 1.

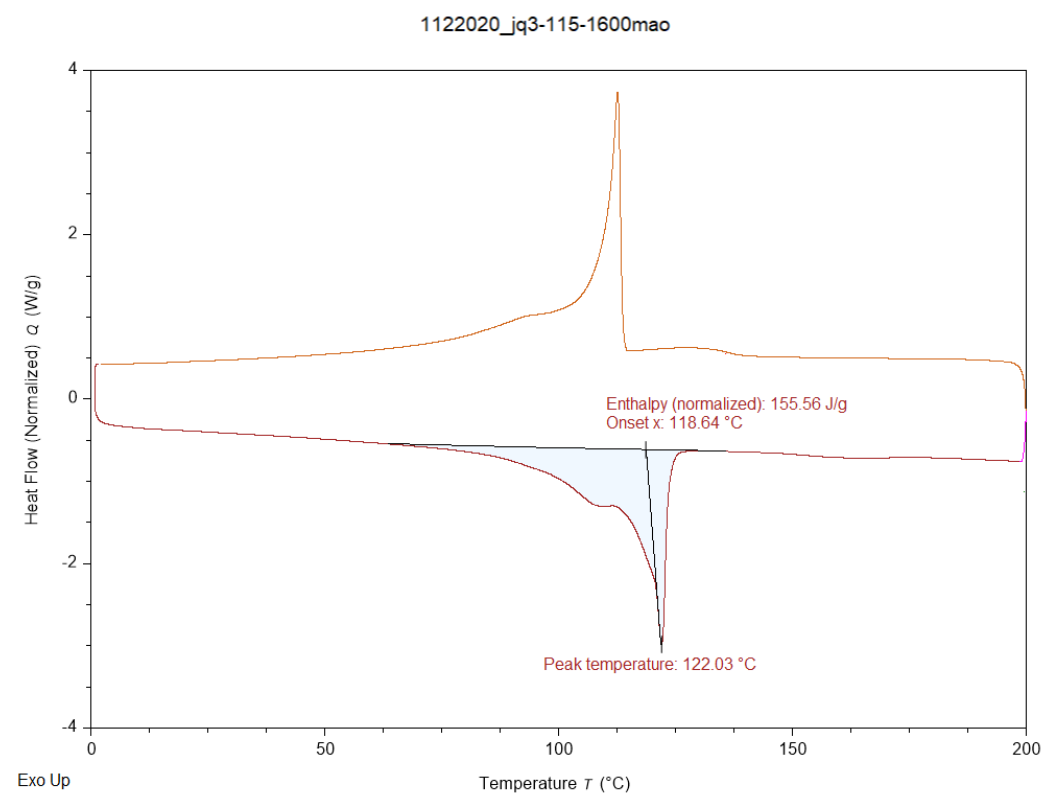

Figure S4.4. Differential scanning calorimetry thermogram for Table S5.2, entry 7. 


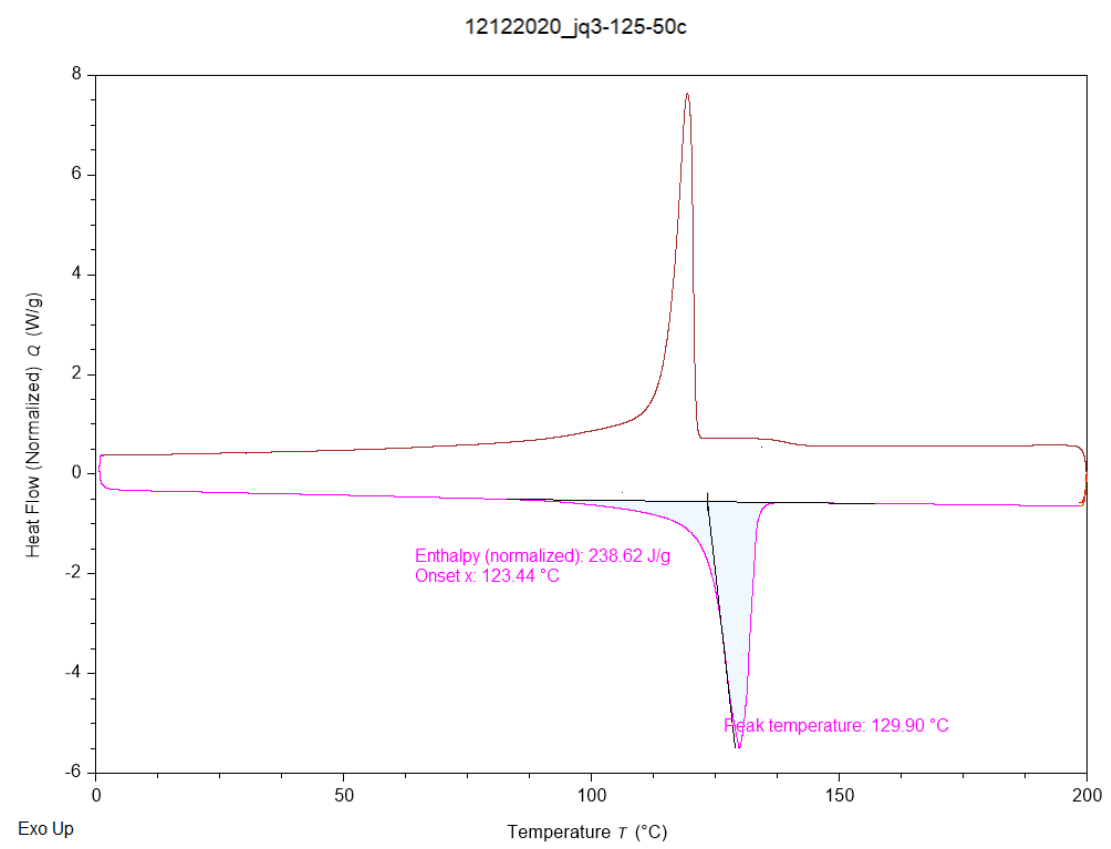

Figure S4.5. Differential scanning calorimetry thermogram for Table S5.3, entry 2.

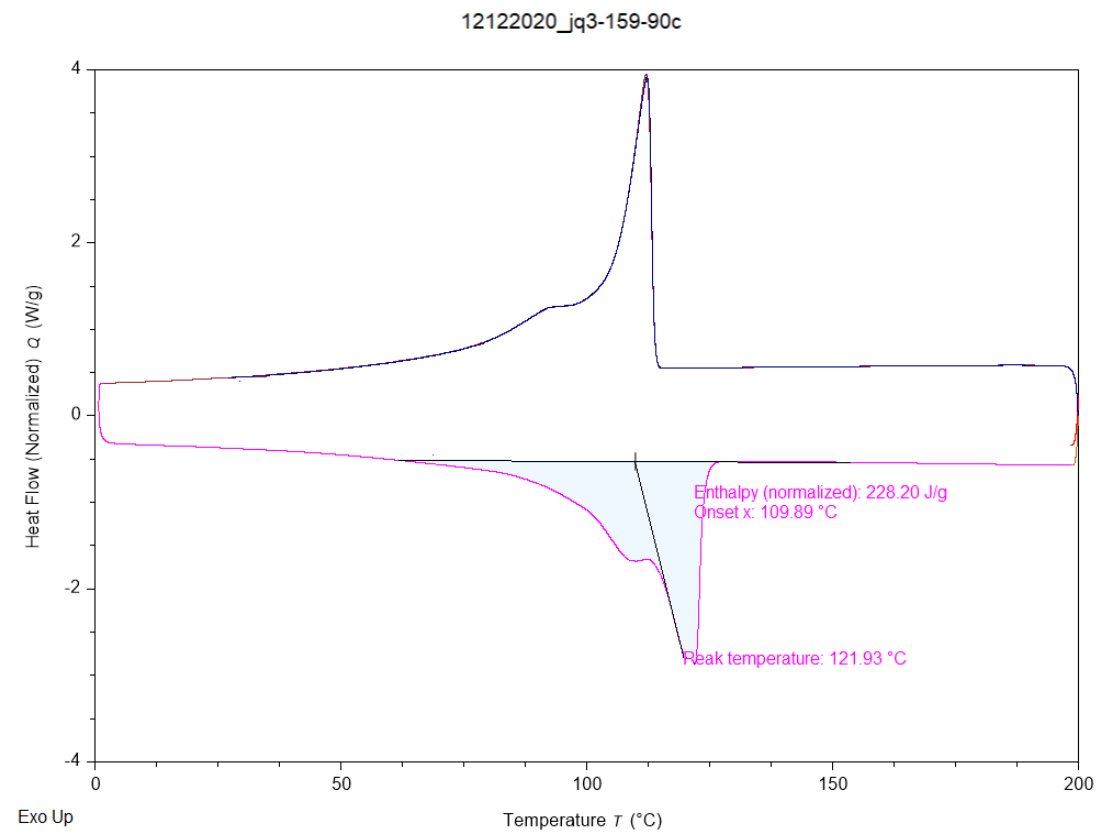

Figure S4.6. Differential scanning calorimetry thermogram for Table S5.3, entry 4. 


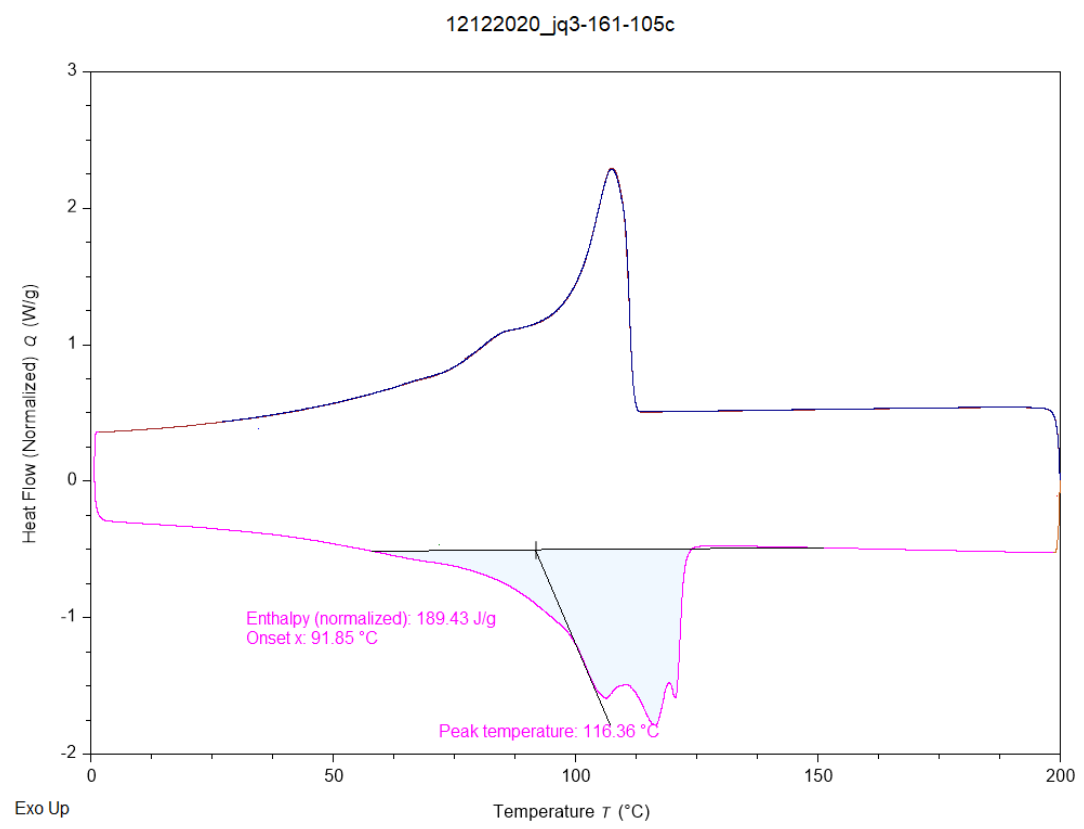

Figure S4.7. Differential scanning calorimetry thermogram for Table S5.3, entry 5.

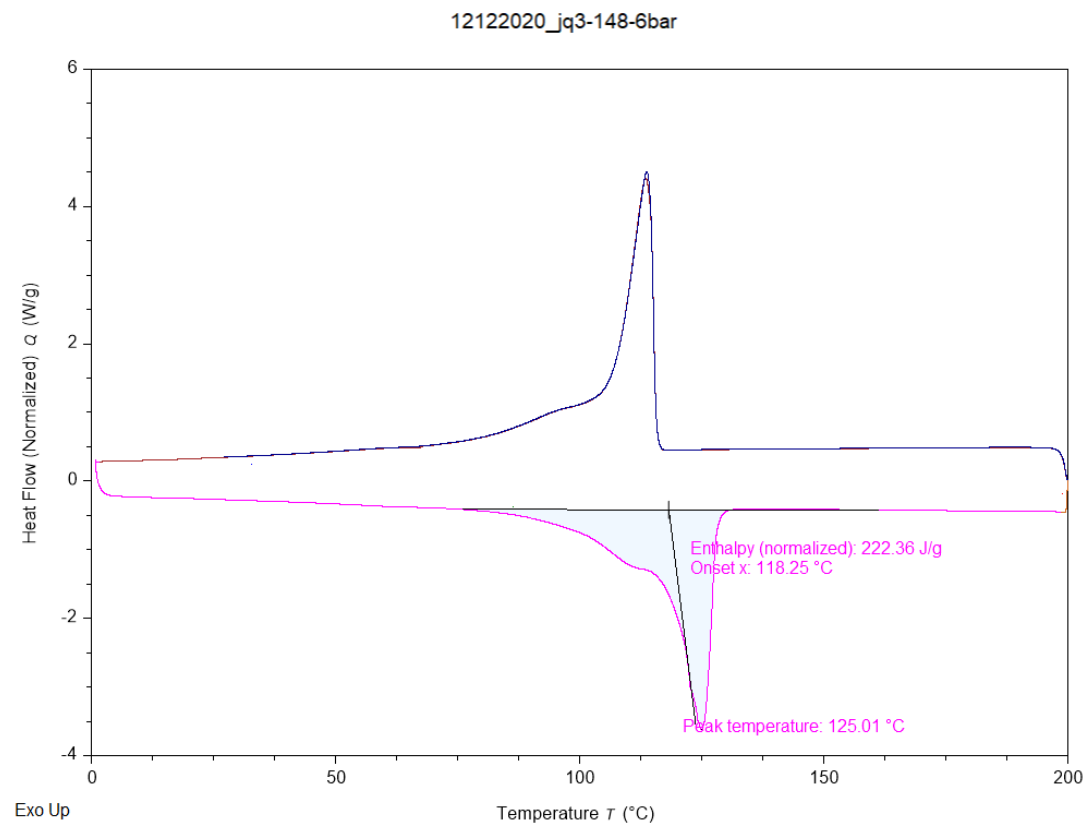

Figure S4.8. Differential scanning calorimetry thermogram for Table S5.4, entry 2. 


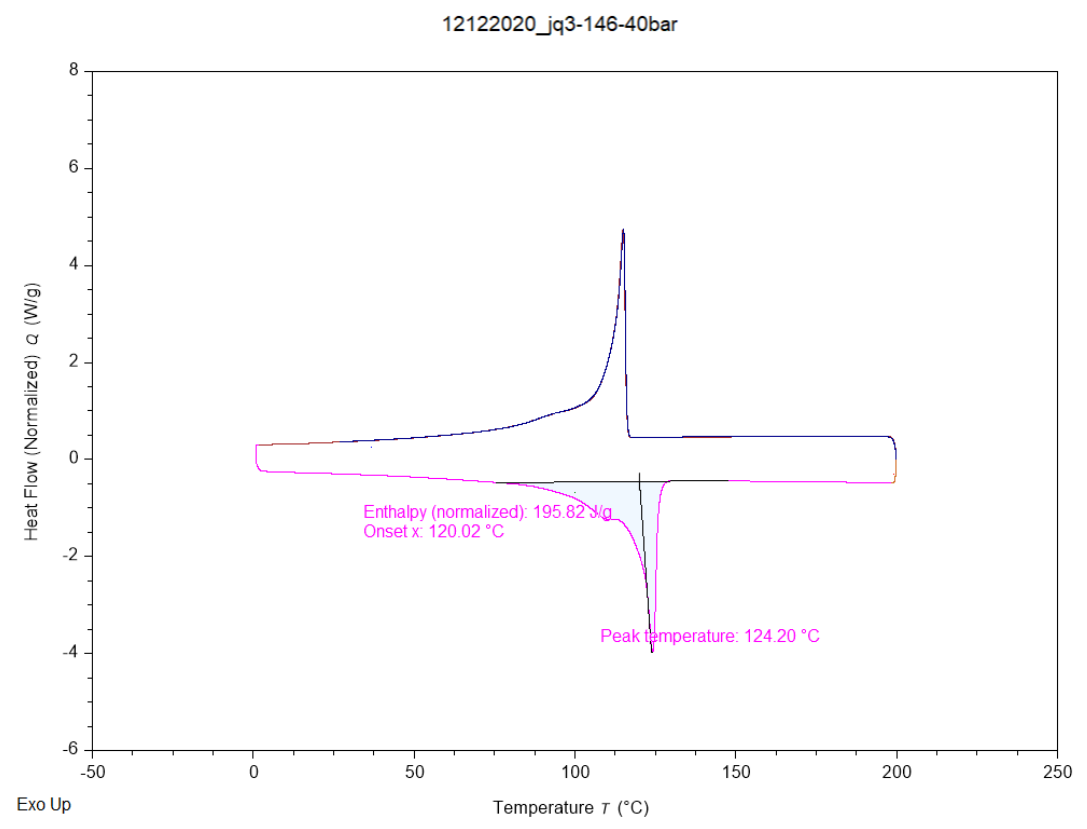

Figure S4.9. Differential scanning calorimetry thermogram for Table S5.4, entry 5. 


\section{S8. Spectral data for Polymer Products}

\section{S8.1. ${ }^{1} \mathrm{H}-\mathrm{NMR}$ analysis of polymer products.}

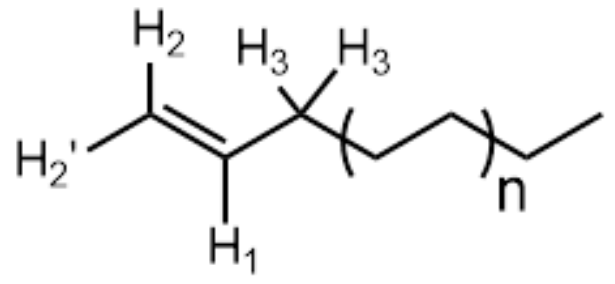

Figure S5.1. Assignment of polymer signals for ${ }^{1} \mathrm{H}-\mathrm{NMR}$ analysis.

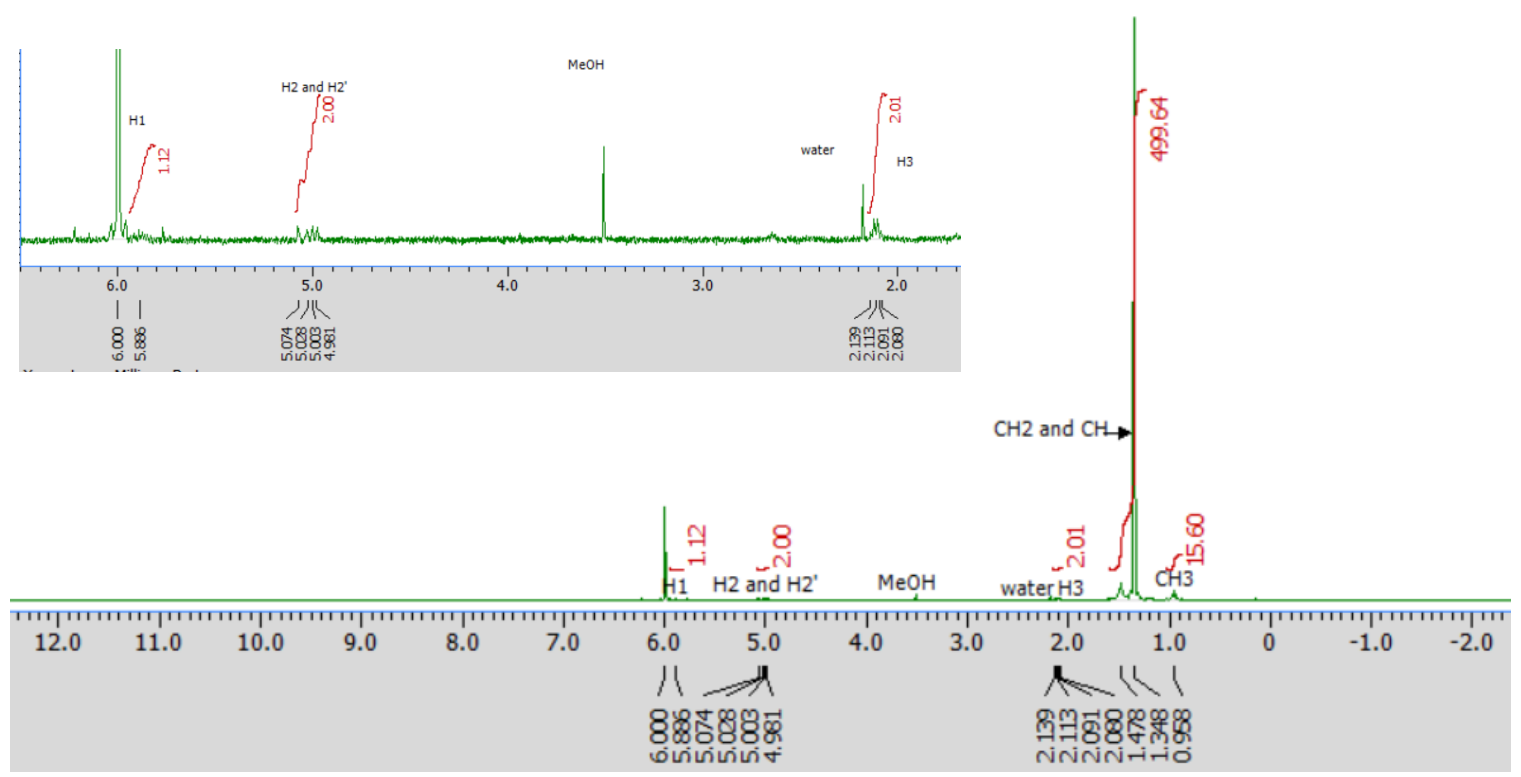

Figure S5.2. Assigned ${ }^{1} \mathrm{H}-\mathrm{NMR}$ spectrum of polyethylene obtained with $0.0065 \mathrm{mmol} 1 \mathrm{in} 10 \mathrm{~mL}$ toluene, 400 eq. of MMAO and 10 bar ethylene at $75^{\circ} \mathrm{C}$ for 1 hour, Table 1, entry 1. 


\section{S9. Gas chromatography analysis of reaction mixture}

\section{S9.1 General procedure}

Polymerization was carried out in toluene in a $50 \mathrm{~mL}$ Parr reactor equipped with a magnetic stir bar. The Parr reactor was evacuated and refilled with $\mathrm{N}_{2}$ three times at $75^{\circ} \mathrm{C} .0 .0065$ mmol 1 and $0.07 \mathrm{mmol}$ mesitylene in $10 \mathrm{~mL}$ toluene was introduced into the nitrogenpurged reactor and stirred vigorously. The toluene was kept at a prescribed polymerization temperature, and then a solution of 400 eq. MMAO-12 in toluene was injected. After 5 min, ethylene gas feed was started, and the pressure was 10 bar. After 1 hour, the ethylene feed was stopped. The reactor was put into an acetone/dry ice bath. The reactor was slowly vented at $0{ }^{\circ} \mathrm{C} .5 \mathrm{ml}$ water was slowly injected into the reaction to quench $\mathrm{MAO}$ and the reaction was allowed to warm to room temperature under stirring. The reaction mixture was filtrated through a syringe filter and dried through $\mathrm{Na}_{2} \mathrm{SO}_{4}$ before submitted to GC.

\section{S9.2 Gas chromatography result}

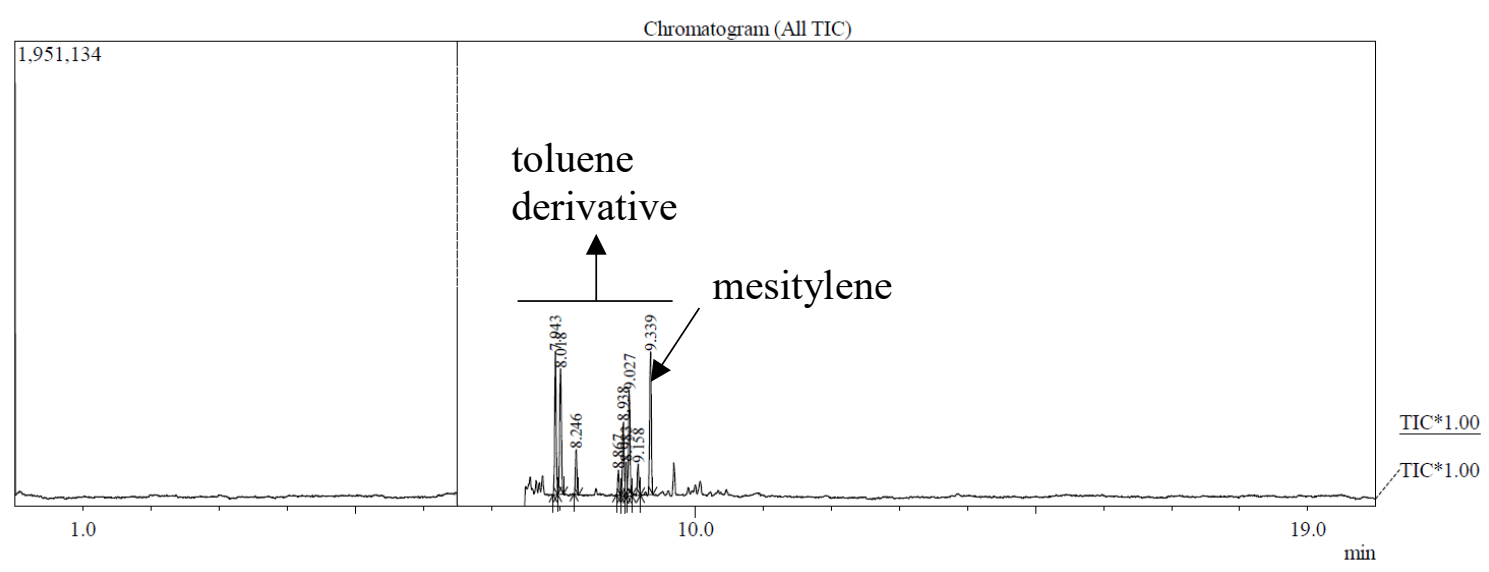




\section{S10. Comparison with Reported Vanadium Catalysts at High}

\section{Temperature}
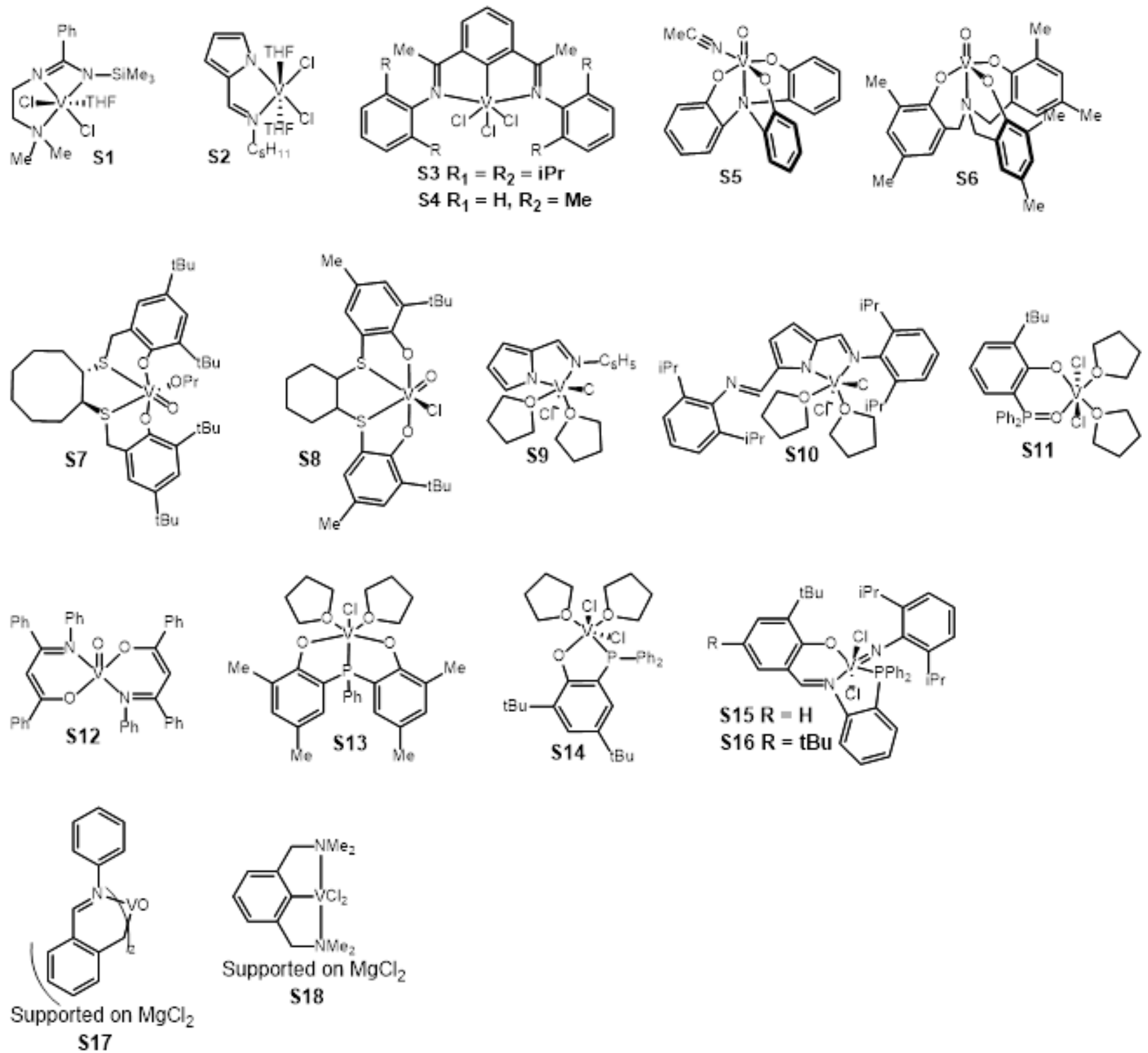

Figure S6. Reported catalysts with olefin polymerization activity at moderate temperature. 
Table S3.1. Reported catalysts with olefin polymerization activity at moderate temperature $\left(70{ }^{\circ} \mathrm{C}\right.$ to $\left.100^{\circ} \mathrm{C}\right)$.

\begin{tabular}{|c|c|c|c|c|c|}
\hline Entry & Catalyst & $\begin{array}{l}\text { Activity } \\
\left(\mathrm{kg} / \mathrm{mol}^{*} \mathrm{~h}\right)\end{array}$ & Temperature & $\begin{array}{l}\text { Run } \\
\text { time }\end{array}$ & Reference \\
\hline 1 & S1 / $\mathrm{AlEt}_{2} \mathrm{Cl}$ & 276 & $80^{\circ} \mathrm{C}$ & $30 \mathrm{~min}$ & $\begin{array}{l}\text { Branmdsma, M. J. R.; Brusse, E. A. C.; Meetsma, } \\
\text { A.; Hessen, B.; Teuben, J. H. Eur. J. Inorg. } \\
\text { Chem. 1998, l, } 867 \text {. }\end{array}$ \\
\hline 2 & $\mathbf{S 2} / \mathrm{AlEt}_{2} \mathrm{Cl}$ & 12900 & $70^{\circ} \mathrm{C}$ & $30 \mathrm{~min}$ & $\begin{array}{l}\text { Xu, B.-C. Hu, T.; Wu, J.-Q.; Hu, N.-H.; Li, Y.-S. } \\
\text { Dalton. Trans. 2009, } 8854\end{array}$ \\
\hline 3 & S3/PMAO & 2243 & $50^{\circ} \mathrm{C}$ & $30 \mathrm{~min}$ & $\begin{array}{l}\text { Reardon, D., Conan, F., Gambarotta, S., Yap, G., } \\
\text { Wang, Q., J. Am. Chem. Soc., 1999, 121, 9318- } \\
9325 .\end{array}$ \\
\hline 4 & S4/MAO & 580 & $60^{\circ} \mathrm{C}$ & $30 \mathrm{~min}$ & $\begin{array}{l}\text { Schmidt, R., Welch, M.B., Knudsen, R.D., } \\
\text { Gottfried, S. Alt, H.G., J. Mol. Catal. A Chem., } \\
\text { 2004, 222,17-25 }\end{array}$ \\
\hline 5 & $\mathrm{~S} 5 / \mathrm{AlMe}_{2} \mathrm{Cl} / \mathrm{ETA}$ & 2300 & $80^{\circ} \mathrm{C}$ & $15 \mathrm{~min}$ & $\begin{array}{l}\text { Redshaw, C.; Rowan, M. A.; Homden, D. M.; } \\
\text { Dale, S. H.; Elsegood, M. R. J.; Matsui, S.; } \\
\text { Matsuura, S., Chem. Commun. 2006, 3329-3331. }\end{array}$ \\
\hline 6 & $\mathrm{~S} 6 / \mathrm{AlMe}_{2} \mathrm{Cl} / \mathrm{ETA}$ & 96500 & $80^{\circ} \mathrm{C}$ & $15 \mathrm{~min}$ & $\begin{array}{l}\text { Redshaw, C.; Rowan, M. A.; Homden, D. M.; } \\
\text { Dale, S. H.; Elsegood, M. R. J.; Matsui, S.; } \\
\text { Matsuura, S., Chem. Commun. 2006, 3329-3331. }\end{array}$ \\
\hline 7 & $\mathrm{~S} 7 / \mathrm{AlEt}_{2} \mathrm{Cl} / \mathrm{ETA}$ & 0.52 & $70^{\circ} \mathrm{C}$ & $24 \mathrm{~h}$ & $\begin{array}{l}\text { Toda, T.; Nakata, N.; Matsuo, T.; Ishii, A., ACS } \\
\text { Catal. 2013, 3, 1764-1767. }\end{array}$ \\
\hline 8 & $\mathrm{~S} 8 / \mathrm{MAO}$ & 168 & $60^{\circ} \mathrm{C}$ & $1 \mathrm{~h}$ & $\begin{array}{l}\text { Meppelder, G.-J.; Halbach, T. S.; Spaniol, T. P.; } \\
\text { Mulhaupt, R.; Okuda, J. A., J. Organometal. } \\
\text { Chem. 2009, 694, 1235-1237. }\end{array}$ \\
\hline 9 & S9/AlEt ${ }_{2} \mathrm{Cl} / \mathrm{ETA}$ & 12900 & $75^{\circ} \mathrm{C}$ & $5 \mathrm{~min}$ & $\begin{array}{l}\text { Mu, J.-S.; Shi, X.-C.; I, Y.-S. J. Polym. Sci. Part } \\
\text { A. Polym. Chem. 2011, 49, 2700-2708. }\end{array}$ \\
\hline 10 & ${\mathrm{~S} 10 / \mathrm{AlEt}_{2} \mathrm{Cl} / \mathrm{ETA}}$ & 22200 & $75^{\circ} \mathrm{C}$ & $5 \mathrm{~min}$ & $\begin{array}{l}\text { Mu, J.-S.; Wang, Y.-X.; Li, B.-X.; Li, Y.-S. } \\
\text { Dalton Trans. 2011, 40, 3490-3497. }\end{array}$ \\
\hline 11 & $\mathrm{~S} 11 / \mathrm{AlEt}_{2} \mathrm{Cl} / \mathrm{ETA}$ & 26400 & $70^{\circ} \mathrm{C}$ & $5 \mathrm{~min}$ & $\begin{array}{l}\text { Zhang, S.-W.; Lu, L.-P.; Long, Y.-Y.; Li, Y.-S. J. } \\
\text { Polym. Sci. Part A. Polym. Chem. 2013, 51, } \\
\text { 5298-5306. }\end{array}$ \\
\hline 12 & $\mathrm{~S} 12 / \mathrm{AlEt}_{2} \mathrm{Cl} / \mathrm{ETA}$ & 23760 & $70^{\circ} \mathrm{C}$ & $5 \mathrm{~min}$ & $\begin{array}{l}\text { Wu, J.-Q.; Li, B.-X.; Zhang, S.-W.; Li, Y.-S. J. } \\
\text { Polym. Sci. Part A. Polym. Chem. 2010, } 48, \\
\text { 3062-3072. }\end{array}$ \\
\hline 13 & $\mathrm{~S} 13 / \mathrm{AlEt}_{2} \mathrm{Cl} / \mathrm{ETA}$ & 16800 & $70^{\circ} \mathrm{C}$ & $5 \mathrm{~min}$ & $\begin{array}{l}\text { Zhang, S.W.; Zhang, G.-B.; Lu, L.-P.; Li, Y.-S. J. } \\
\text { Polym. Sci. Part A. Polym. Chem. 2013, 51, 844- } \\
\text { 854. }\end{array}$ \\
\hline 14 & ${\mathrm{~S} 14 / \mathrm{AlEt}_{2} \mathrm{Cl} / \mathrm{ETA}}$ & 29500 & $70^{\circ} \mathrm{C}$ & $5 \mathrm{~min}$ & $\begin{array}{l}\text { Zhang, S.-W.; Lu, L.-P.; Li, B.-X.; Li, Y.-S. J. } \\
\text { Polym. Sci. Part A. Polym. Chem. 2012, 50, } \\
\text { 4721-4731. }\end{array}$ \\
\hline 15 & $\mathrm{~S} 15 / \mathrm{AlEt}_{2} \mathrm{Cl} / \mathrm{ETA}$ & 133800 & $75^{\circ} \mathrm{C}$ & $10 \mathrm{~min}$ & $\begin{array}{l}\text { Lu, L.-P.; Wang, J.-B.; Liu, J.-Y.; Li, Y.-S. J. } \\
\text { Polym. Sci. Part A. Polym. Chem. 2014, 52, } \\
\text { 2633-2642. }\end{array}$ \\
\hline 16 & $\mathrm{~S}_{17 / \mathrm{AlMe}_{3}}$ & 65100 & $75^{\circ} \mathrm{C}$ & $15 \mathrm{~min}$ & $\begin{array}{l}\text { Nakayama, Y.; Bando, H.; Sonobe, Y.; Suzuki, } \\
\text { Y.; Fujita, T. Chem. Lett. 2003, 32, } 766\end{array}$ \\
\hline
\end{tabular}




\begin{tabular}{|l|l|l|l|l|l|}
\hline 17 & S18/AlEt $2.11(\mathrm{OEt})_{0.89}$ & 19900 & $70^{\circ} \mathrm{C}$ & $1 \mathrm{~h}$ & $\begin{array}{l}\text { Chuchuryukin, A. V.; Huang, R.; van Faassen, E. } \\
\text { E.; van Klink, G. P. M.; Lutz, M.; Chadwick, J. } \\
\text { C.; Spek, A. L.; van Koten, G. Dalton Trans. } \\
\mathbf{2 0 1 1}, 40,8887-8895 .\end{array}$ \\
\hline
\end{tabular}

Table S3.2. Reported catalysts with olefin polymerization activity at moderate temperature (over $100^{\circ} \mathrm{C}$ ).

\begin{tabular}{|c|c|c|c|c|c|}
\hline Entry & Catalyst & $\begin{array}{l}\text { Activity } \\
\text { (kg/mol*h) }\end{array}$ & Temperature & Run time & Reference \\
\hline 1 & S3/PMAO & 612 & $140^{\circ} \mathrm{C}$ & $10 \mathrm{~min}$ & $\begin{array}{l}\text { Reardon, D., Conan, F., } \\
\text { Gambarotta, S., Yap, G., Wang, Q., } \\
\text { J. Am. Chem. Soc., 1999, 121, 9318- } \\
\text { 9325. }\end{array}$ \\
\hline 2 & $\mathrm{~S} 16 / \mathrm{AlEt}_{2} \mathrm{Cl} / \mathrm{ETA}$ & 14900 & $100^{\circ} \mathrm{C}$ & $10 \mathrm{~min}$ & $\begin{array}{l}\text { Lu, L.-P.; Wang, J.-B.; Liu, J.-Y.; } \\
\text { Li, Y.-S. J. Polym. Sci. Part A. } \\
\text { Polym. Chem. 2014, 52, 2633-2642. }\end{array}$ \\
\hline
\end{tabular}

